\title{
G-quadruplex stabilization in the ions and maltose transporters inhibit Salmonella enterica growth and virulence.
}

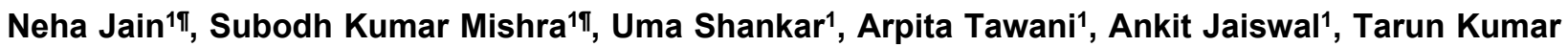

Sharma ${ }^{2}$, Prashant Kodgire ${ }^{1}$ and Amit Kumar ${ }^{1 *}$.

${ }^{1}$ Discipline of Biosciences and Biomedical Engineering, Indian Institute of Technology Indore, Indore, Simrol, Indore, 453552, India

${ }^{2}$ Centre for Bio-design and Diagnostics, Translational Health Science and Technology Institute, Faridabad, Haryana, India.

IT These authors contributed equally to this work

*Corresponding Author. Email: amitk@iiti.ac.in 


\begin{abstract}
The G-quadruplex structure forming motifs have recently emerged as a novel therapeutic drug target in various human pathogens. Herein, we report three highly conserved G-quadruplex motifs (SE-PGQ-1, 2, and3) in genome of all the 412 strains of Salmonella enterica. Bioinformatics analysis inferred the presence of SE-PGQ-1 in the regulatory region of $m g t A$, presence of SE-PGQ-2 in the open reading frame of entA and presence of SE-PGQ-3 in the promoter region of malE and malK genes. The products of $m g t A$ and entA are involved in transport and homeostasis of $\mathrm{Mg}^{2+}$ and $\mathrm{Fe}^{3+}$ ion and thereby required for bacterial survival in the presence of reactive nitrogen/oxygen species produced by the host macrophages, whereas, malK and malE genes are involved in transport of maltose sugar, that is one of the major carbon source in the gastrointestinal tract of human. The formation of stable intramolecular G-quadruplex structures by SE-PGQs was confirmed by employing CD, EMSA and NMR spectroscopy. Cellular studies revealed the inhibitory effect of 9-amino acridine on Salmonella enterica growth. Next, CD melting analysis demonstrated the stabilizing effect of 9-amino acridine on SE-PGQs. Further, polymerase inhibition and RT-qPCR assays emphasize the biological relevance of predicted G-quadruplex in the expression of PGQ possessing genes and demonstrate the G-quadruplexes as a potential drug target for the devolping novel therapeutics for combating Salmonella enterica infection.
\end{abstract}

\title{
Author Summary
}

Since last several decades' scientific community has witnessed a rapid increase in number of such human pathogenic bacterial species that acquired resistant to multiple antibacterial agents. Currently, emergence of multidrug-resistant strains remain a major public health concern for clinical investigators that rings a global alarm to search for novel and highly conserved drug targets. Recently, G-quadruplex structure forming nucleic acid sequences were endorsed as highly conserved Drug target for preventing infection of several human pathogens including viral and protozoan species. Therefore, here we explored the presence G-quadruplex forming motif in genome of Salmonella enterica bacteria that causes food poisoning, and enteric fever in human. The formation of intra molecular G-quadruplex structure in four genes (mgtA, entA, malE and malK) was confirmed by NMR, CD and EMSA. The 9-amino acridine, a 
known G-quadruplex binder has been shown to stabilize the predicted G-quadruplex motif and decreases the expressioin of G-quadruplex hourbouring genes using RT-PCR and cellular toxicity assay. This study concludes the presence of G-quadruplex motifs in essential genes of Salmonella enterica genome as a novel and conserved drug target and 9-amino acridine as candidate small molecule for preventing the infection of Salmonella enterica using a G4 mediated inhibition mechanism.

\section{Introduction}

Salmonella enterica belongs to Enterobacteriaceae family and known to cause typhoid fever and food poisoning in the human. Salmonella enterica consists of six subspecies namely 1) enterica 2) salamae 3) arizonae 4) diarizonae 5) houtenae 6) indica (Fig 1a). Among these subspecies, subspecies S. enterica is known to infect human and possess $\sim 2463$ serovars that can be further divided into two subclasses[1, 2]. Typhoidal class of S. enterica included S. enterica subsp. enterica ser. Typhi(S. ser. Typhi) and S. enterica subsp. enterica ser. Paratyphi (S. ser. Paratyphi) known to causes typhoid or enteric fever, whereas non-typhoidal class includes S. enterica subsp. enterica ser. Enteritidis (S. ser. Enteritidis) and S. enterica subsp. enterica ser. Typhimurium ( $S$. ser. Typhimurium), and causes food poisoning in human[3]. They have been reported for causing more than $\sim 140$ foodborne illness throughout the world [4-8]. As per the Centers for Disease Control and Prevention (CDC), typhoid fever causes $\sim 22$ million new cases and $\sim 200,000$ deaths every year across the world $[9,10]$. The emergence of antimicrobial drug resistance for chloramphenicol, co-trimoxazole, ampicillin, ciprofloxacin, ofloxacin, azithromycin and cephalosporin make the situation more dangerous and thus leading to increased death rate due to clinical treatment failure [11-13]. More recently, severe complications with Salmonella species have emerged and connected to multiple invasive disorders like irritable bowel syndrome [14], reactive arthritis[15], bacteremia[16] focal infection[17], meningitis[18] and infectious aortitis[19]. Due to its high prevalence and rapid emergence of drug resistance, Salmonella ring a global alarm for the development of novel and promising therapeutic approaches. A more effective and efficient therapeutic approach would be required to target the expression of those genes that were previously observed to be associated with essential nutrient acquisition system and remained conserved throughout the evolution in the genome of this deadly human pathogen. 
S. enterica is an intracellular pathogen that grows in phagocytes and macrophages. During the growth phase, the host innate immune system generate various oxidative stresses to eradicate this pathogen. However, S. enterica possess a magnesium homeostasis mechanism that controls the intracellular $\mathrm{Mg}^{2+}$ concentration and helps bacteria to survive in nitro-oxidative stressed condition[20]. Magnesium homeostasis is also required for virulence, thermo-tolerance and survival of $S$. enterica [21]. The bacteria contain three genes that help in $\mathrm{Mg}^{2+}$ uptake from the host namely: i) $m g t A$, ii) $m g t B$, and iii) corA. Neutralization of the reactive nitrogen stress(RNS, nitro-oxidative) is mainly regulated by $\mathrm{Mg}^{2+}$ transport ATPase that is encoded by $m g t A$ gene and therefore plays a vital role in the bacterial survival inside macrophage (Fig 2a) [22]. Hence, targeting the conserved region of $m g t A$ gene may serve as a promising therapeutic approach to combat with S. enterica pathogenesis.

Similar to $\mathrm{Mg}^{2+}$ ion, iron is also required by this bacteria, but its uptake from the host environment is more challenging as it gets sequestered by various host proteins like siderocalin, transferrin and lactoferrin leading to its unavailability in the host environment (Fig 2b). S. enterica produces enterobactin and salmochelin, two low molecular weight catecholate type siderophores that have a high affinity for Iron than the host iron-binding proteins. These enterobactin/salmochelin are produced from chorismate that requires several enzymes encoded by a co-transcribed entABCDEF operon (Fig 2b). [23]. The conversion of the 2,3-dihydro-2,3-dihydroxybenzoate (2,3 DHB) to another intermediate 2,3-dihydroxybenzoate(DHB) is a crucial step of this pathway and required a 2,3-dihydro-2,3-dihydroxybenzoate dehydrogenase enzyme(EntA), encoded by entA gene of entABCDEF operon. The inhibition of entA gene expression has been observed to abolish the DHB formation leading to the reduced production of bacteriocin and salmochelin[24]. Interestingly, salmochelin are resistant to antimicrobial peptides (lipocalins), secreted by the host cells and acts as an essential factor in the pathogenesis of systemic $S$. ser. Thyphimurium infection [25]. Salmoechelins also protects this bacteria from reactive oxygen superoxides (ROS) mediated oxidative stress[26]. Targeting the production of siderophore has previously shown to have antimicrobial activity against Mycobacterium tuberculosis [27], Aspergillus fumigatus[28], Yersinia pestis[29], Pseudomonas aeruginosa[30], Bacillus substilis, Acinetobacter baunamnni and Vibrio chloreae[31]. Therefore, targeting entA gene may prove as another therapeutic approach to combat the infection and virulence of $S$. enterica as well. 

aCC-BY 4.0 International license.

S. enterica grows in the gastrointestinal tract of humans that has an ample amount of maltose and maltodextrin. Therefore, along with glucose, S. enterica utilizes maltose as major source of carbon. The uptake of maltose from host environment is tightly regulated by two genes, malK and malE(Fig 2c) [32]. Inhibiting the malK and malE synthesis have shown to decline the growth rate of $S$. enterica [33]. Henceforth, targeting these genes will make S. enterica unable to grow inside the gastrointestinal tract.

DNA along with its canonical B-form can also fold into a non-canonical G-quadruplex (G4) structure. $G$ rich regions having a motif $G_{2} N_{L} G_{\geq 2} N_{L} G_{\geq 2} N_{L} G_{\geq 2}$ present in the genome tends to form specific secondary structures known as G-quadruplex (G4). G4s are stabilized by the presence of monovalent and some divalent cations, in the order of $\mathrm{K}^{+}>\mathrm{Na}^{+}>\mathrm{Mg}^{2+}>\mathrm{Li}^{+}$and can adopt various topologies (Fig $1 \mathrm{~b}$ \& 1c) $[34,35]$. This structural diversity has been exploited for the diagnosis and therapeutic targeting[36, 37]. G4s are highly ordered and shown to be evolutionarily conserved in eukaryotes [38] prokaryotes[39], protista[40], plants[41] and viruses[42]. Presence of G4 binding proteins and antibody-based approaches have confirmed their presence in-vivo and are reported to play a regulatory role in the expression of genes such as regulating DNA replication by the specification of origin of replication(ORI) sites, telomere maintenance in human cells, antigenic variations by regulating recombination, transcription, and translation[43]. G4 motifs present in the telomere regions of the chromosomes and promoter regions of oncogenes like Bcl, c-Kit, MYC, KRAS, etc. have been explored in various human cancers[44, 45].

Currently, G4s are being investigated for their involvement in virulence and survival mechanisms of various human pathogen[46]. Stabilization of $\mathrm{G} 4 \mathrm{~s}$ in protozoans: Plasmodium falciparum, Trypanosoma brucei and Leishmania donovani have shown anti-protozoal activities [47]. Further, G4s have emerged as promising drug target in viruses like SARS coronavirus, Human Papilloma virus(HPV), Zika virus, Ebola virus, Herpes simplex virus(HSV), Epstein-Barr virus(EBV), Hepatitis B virus(HBV), Hepatitis C virus(HCV), Human immunodeficiency virus 1(HIV-1), etc. where they play an essential role in viral proliferation and pathogenicity[42]. In bacteria, G4 present at the upstream of pilE locus, B31 vIsE locus and tprK antigen protein in Neisseria gonorrhoea, Borrelia burgdorferi, and Treponema pallidum, respectively acts as an activator for the initiation of antigenic variation and helps the pathogens in bypassing immune system of the host cells[46]. In Deinococcus radiodurans, G4 sequences were 
present in the regulatory regions of various genes and contributes to radio resistance [48]. G4 present at the $150 \mathrm{nt}$ upstream of nasT in the soil bacterium Paracoccus denitrificans PD1222 isreported to be involved in nitrite assimilation[49].

All these reports demonstrated the pivotal role of G-quadruplex in human pathogens and their conserved-ness suggest them as a promising drug target for both drug susceptible and drug-resistant strains of human pathogens. Therefore, a comprehensive study that discovers highly conserved Gquadruplex in the genome of $S$. enterica as a drug target may provide as a most suitable therapeutic approach for fighting against the infection of this deadly pathogen and overcome the emergence of drugresistant problem in this bacterium.

In present study, we sought to explore the highly conserved potential G-quadruplex forming sequences (SE-PGQs) in all the available and completely sequenced 412 strains of $S$. enterica. Bioinformatics sequence analysis revealed the presence of three SE-PGQs (SE-PGQ 1-3) in three different gene locations of S. enterica genome. The SE-PGQ-1 was found to be present in the regulatory region of $m g t A$, SE-PGQ-2 in the open reading frame of entA, whereas SE-PGQ-3 found to lie in the regulatory region of malK and malE genes (Fig 3a). In order to confirm the formation of G-quadruplex structure by SE-PGQs, Circular Dichroism spectroscopy (CD), gel mobility shift assay (EMSA) and one dimensional ${ }^{1} \mathrm{H}$ NMR spectroscopy were employed. Further to validate these SE-PGQ as a potential drug target, CD melting, and Taq polymerase stop assay were performed that confirmed 9-amino-acridine, a known G4 binding molecule interact and stabilizes the SE-PGQs motifs with high affinity and selectivity over the duplex DNA. Disc diffusion assay and MTT cytotoxicity assay confirmed the growth inhibition of S. enterica cells by 9-amino acridine molecule. Further, Real-time -quantitative PCR (RT-qPCR) revealed the reduced expression of genes that harbor the SE-PGQs in either their coding region or regulatory region upon the treatment with 9-amino acridine. This change in the expression of PGQs harboring gene in the presence of G4 binding ligand suggested a G4 mediated regulatory mechanism in the expression of these genes.

As mentioned above, these genes are essential for bacterial survival and virulence inside the host macrophages. Therefore, G-quadruplex motifs found in these genes can be utilized as a potential drug 
target to develop a promising anti-microbial therapeutics. Moreover, the high conserved-ness of these SE-PGQs, even in the drug-resistant strain would overcome the problem of emergence of drug-resistance in S. enterica.

\section{Result}

\section{Salmonella enterica genome harbors three most conserved G-quadruplexes}

A comprehensive mining of potential G-quadruplex forming motifs (SE-PGQs) was performed on 412 completely sequenced strains of S. enterica (Supplementary Table S1). The bioinformatics analysis observed a total of 109400 PGQs in 412 strains of S. enterica (Supplementary File S2). Given that, the similar sequence may correspond to similar structure and evolutionarily conserved function, all the predicted PGQs were further clustered by Unweighted Pair Group Method with Arithmetic Mean clustering method using Clustal Omega tool. The conserved-ness is an essential parameter that makes these PGQ motifs suitable to work as promising drug targets. Therefore, next we examined the conservation of each PGQ clustered using the following equation:

$$
p=(n \div N) \times 100
$$

Where $p$ is the frequency of occurrence, $\mathrm{n}=$ number of strains with specific G4 sequence, and $\mathrm{N}$ represents the total number of strains of $S$. enterica. These, conservation analysis revealed $187 \mathrm{PGQ}$ clusters that were observed to possess conversed-ness in more than $90 \%$ strains of $S$. enterica. (Supplementary Table S3). G-quadruplex with loop length 1-7 and G tract of $\geq 3$ forms more stable Gquadruplex[50]. Therefore, for the further study, we selected only those PGQs that satisfying the aforesaid criteria of G-quadruplex formation and were listed in Table 1.

Table 1: List of PGQs with G-tract $\geq 3$ and loop length $1 \leq L \geq 7$ and conserved in $90 \%$ Salmonella enterica along with their gene IDs, locations, functions, and gene name.

\begin{tabular}{|c|c|c|c|c|c|c|c|}
\hline \# PGQs & G4 Sequences & $\begin{array}{c}\% \text { of } \\
\text { conservati } \\
\text { vity }\end{array}$ & Gene ID & Start & End & Associated Function & G4 strand \\
\hline SE-PGQ-1 & GGGAGAGGGGTGGGTTCAGGG & 99.32 & - & 4655597 & 4655577 & $\begin{array}{lr}\text { Upstream of } & \text { magnesium- } \\
\text { translocating } & \text { P-type }\end{array}$ & Antisense \\
\hline
\end{tabular}




\begin{tabular}{|c|c|c|c|c|c|c|c|}
\hline & & & & & & ATPase mgtA (1250998) & \\
\hline SE-PGQ-2 & GGGTGACCGGGGCGGGGAAAGGG & 98.54 & 1247106 & 644073 & 644095 & $\begin{array}{l}\text { 2,3-dihydro-2,3- } \\
\text { dihydroxybenzoate } \\
\text { dehydrogenase (ent } A \text { ) }\end{array}$ & Sense \\
\hline SE-PGQ-3 & GGGGTGGGGCGTAGGGGCGGGG & 99.27 & - & 4295743 & 4295722 & $\begin{array}{l}\text { Intergenic region between } \\
\text { maltose/maltodextrin ABC } \\
\text { transporter substrate- } \\
\text { binding protein malE } \\
{[1250642 \text { ](103 bp upstream) }} \\
\text { and maltose/maltodextrin } \\
\text { import ATP-binding protein } \\
\text { malK (1250643) }\end{array}$ & Antisense \\
\hline SE-PGQ-4 & GGGTCGGGCGGGAGGAGGG & 94 & 1250711 & 4387209 & 4387227 & $\begin{array}{lc}\text { (melibiose } & \text { operon } \\
\text { regulatory } & \text { protein) } \\
\text { Transcriptional regulator }\end{array}$ & Sense \\
\hline SE-PGQ-5 & GGGCGGGCCGCTGGGGCAAAGGG & 93 & 1249284 & 2853220 & 2853198 & $\begin{array}{l}\text { hydrogenase } \\
\text { incorporation protein } \text { HypB }^{\text {Hickel }}\end{array}$ & Antisense \\
\hline SE-PGQ-6 & GGGGCGGGACGGGCCTGGGG & 91 & 1250199 & 3820390 & 3820409 & $\begin{array}{lr}\text { TMAO reductase } & \begin{array}{r}\text { system } \\
\text { sistidine }\end{array} \\
\text { sensor } & \text { rinase/response } \\
\text { regulator } \\
\text { Tors }\end{array}$ & Antisense \\
\hline SE-PGQ-7 & $\begin{array}{l}\text { GGGGAATGTGGGCTTCTGGGTAGTG } \\
\text { GG }\end{array}$ & 92 & 1254306 & 2784381 & 2784355 & $\begin{array}{l}\text { HoxN/HupN/NixA family } \\
\text { nickel/cobalt transporter }\end{array}$ & Antisense \\
\hline SE-PGQ-8 & GGGATGGGCGGGAGCGCGGG & 92 & 1248430 & 1937914 & 1937895 & oligopeptidase B & Antisense \\
\hline SE-PGQ-9 & GGGATACTGGGGGGGATGGG & 91 & 1251066 & 4728374 & 4728355 & $\begin{array}{l}\text { aspartate/glutamate } \\
\text { racemase family protein }\end{array}$ & Antisense \\
\hline SE-PGQ-10 & GGGCGGGCAGGGGAGGATTGGGG & 93 & 1246834 & 360658 & 360679 & $\begin{array}{l}\text { hypothetical } \\
\text { probable secreted protein }\end{array}$ & Sense \\
\hline SE-PGQ-11 & GGGATGGGGATCGCGGGCGGG & 91 & 1255592 & 3668716 & 3668696 & MFS transporter & Antisense \\
\hline SE-PGQ-12 & GGGATGCGGGCCAAAGGGCAGGG & 91. & 1250960 & 4615782 & 4615804 & $\begin{array}{ll}\text { EamA/RhaT } & \text { family } \\
\text { transporter } & \end{array}$ & Sense \\
\hline SE-PGQ-13 & GGGCGTATTGGGGTGGGGCGTGGG & 91 & 1247738 & 1298963 & 1298940 & aconitate hydratase 1 & Antisense \\
\hline SE-PGQ-14 & GGGAACAGGGTCAGTGGGAATCGGG & 90 & - & 1360712 & 1360688 & 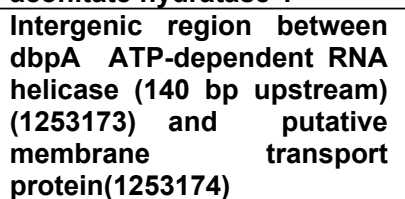 & Antisense \\
\hline SE-PGQ-15 & $\begin{array}{l}\text { GGGTAGTGGGCAATCAGGGATTCGG } \\
\text { G }\end{array}$ & 92 & 1246917 & 451820 & 451795 & $\begin{array}{l}\text { S-adenosylmethionine:tRNA } \\
\text { ribosyltransferase- } \\
\text { isomerase }\end{array}$ & Antisense \\
\hline SE-PGQ-16 & $\begin{array}{l}\text { GGGAAATGGGTATCGTTGGGCGTCG } \\
\text { GG }\end{array}$ & 91 & 1248034 & 1590530 & 1590556 & oxidoreductase & Sense \\
\hline SE-PGQ-17 & $\begin{array}{l}\text { GGGAAATGCTGGGCAGCGTCGGGCG } \\
\text { GGGG }\end{array}$ & 91 & 1246973 & 507029 & 507057 & $\begin{array}{l}\text { thiamin } \\
\text { pyrophosphate hydrolase }\end{array}$ & $\begin{array}{l}\text { Sense } \\
\text { strand }\end{array}$ \\
\hline SE-PGQ-18 & $\begin{array}{l}\text { GGGTATGGGGGTTGTAGGGGTTTGG } \\
\text { CTGGGG }\end{array}$ & 93 & 1248556 & 2051235 & 2051205 & FMN/FAD transporter & Antisense \\
\hline
\end{tabular}

These predictions were further crosschecked with QGRS Mapper and PQSFinder (Supplementary Table S3a and S3b). Interestingly, out of these 18 PGQs clusters, three PGQs (SE-PGQ1, SE-PGQ-2 and SE-PGQ-3) were found to be conserved in more than $98 \%$ strains of $S$. enterica (S2 File) and present in the four essential genes namely $m g t A$, entA, malK and malE (Fig 3). The consensus sequence depicted the conserved G-residues of SE-PGQ motifs during the evolution process Fig 3b. 


\section{In vitro ${ }^{1} \mathrm{H}$ NMR analysis affirms the formation of G-quadruplex}

NMR spectroscopy is considered as a most reliable technique for confirming the formation of Gquadruplex structure formation by the nucleic acid sequences. Therefore $1 \mathrm{D}{ }^{1} \mathrm{H}$ NMR spectroscopy was performed to confirm the formation of G-quadruplex conformation by SE-PGQs. The presence of a chemical shift in the range of $10-12 \mathrm{ppm}$ in $1 \mathrm{D}{ }^{1} \mathrm{H}$ NMR spectra depicts the presence of hoogsteen base pairing in characteristic G-tetrads of G-quadruplex structure whereas, canonical G-C Watson Crick base pairing can be characterized by a chemical shift in the range of 12-14 ppm. All the three SE-PGQs showed an imino proton resonance between 10-12 ppm and clearly affirms the formation of G-quadruplex structure (Fig 4 \& S1 Fig).

\section{Evaluating the topology and stability of the PGQs using Circular Dichroism}

Circular dichroism is one of the widely used techniques for analyzing the topology of the G-quadruplex structure. G-quadruplex, depending upon its sequence, loop length, and bound cation, can form either a parallel, antiparallel or hybrid conformation. A positive peak at $\sim 260 \mathrm{~nm}$ and a negative peak at $\sim 240 \mathrm{~nm}$ signifies for parallel G-quadruplex topology. However, a positive peak at $\sim 290 \mathrm{~nm}$ and a negative peak at $\sim 260 \mathrm{~nm}$ signifies for anti-parallel G-quadruplex topology whereas, two positive peaks at $260 \mathrm{~nm}$ and 290 $\mathrm{nm}$ with a negative peak at $240 \mathrm{~nm}$ depict the mix or hybrid topology [51]. Different cation affects the stability of the G-quadruplex structure in different extent. The ranking of stabilizing ability of some well studied cations is as follows : $\mathrm{K}^{+}>\mathrm{Na}^{+}>\mathrm{Mg}^{2+}>\mathrm{Li}^{+}{ }^{[35]}$. Therefore, we performed the CD spectroscopy of SE-PGQs in four different cations $\left(\mathrm{K}^{+}, \mathrm{Na}^{+}, \mathrm{Li}^{+}\right.$, and $\left.\mathrm{Mg}^{2+}\right)$ containing buffers (Fig 5 \& S2 Fig).

CD spectra analysis revealed the predominant parallel G-quadruplex topology exhibited by SEPGQ-1 and SE-PGQ-3 in the presence of the $\mathrm{K}^{+}$ion, whereas SE-PGQ-2 showed hybrid G-quadruplex topology in the presence of $\mathrm{K}^{+}$(Fig 5a). As expected, CD spectral scanning performed in the increasing concentration of $\mathrm{K}^{+}$ion showed the maximum molar ellipticity in highest $\mathrm{K}^{+}$ion concentration (S3 Fig). Figure $5 b$ shows the $C D$ melting curve of SE-PGQs in various cation conditions. CD melting analysis revealed the higher stability of the SE-PGQs in the $\mathrm{K}^{+}$ion concentration (Figure $5 b$ \& $c$ ). To evaluate the significance of G-tracts for their G-quadruplex forming ability, the central Guanine was mutated to 
Adenine and CD spectra analysis was performed in $50 \mathrm{mM} \mathrm{K}^{+}$ion (S4 Table). Mutants (mut-PGQ-1, mutPGQ-2, and mut-PGQ-3) failed to show the characteristic CD signal of G-quadruplex i.e. a positive band at $260 / 290 \mathrm{~nm}$ and a negative band at $240 \mathrm{~nm}$ suggesting the mutation in $\mathrm{G}$ tract disrupted the Gquadruplex formation (Fig 5a).

\section{Electrophoretic Mobility Shift Assay (EMSA) supports intramolecular conformations of SE-PGQs}

Next, Electrophoretic Mobility Shift assay (EMSA) was performed to check the molecularity (inter or intra molecular G-quadruplex) of SE-PGQ in the solution. An intramolecular G-quadruplexes possess a compact topology and migrate faster than their linear counterpart, whereas intermolecular G-quadruplex contains a comparatively wider topology and exhibited slow migration than their linear counterpart[52]. All the three SE-PGQs and positive control (Tel22 DNA G-quadruplex) showed faster mobility than their respective linear counterpart and therefore suggested the formation of intramolecular G-quadruplex by SE-PGQs (Fig 6).

\section{9-amino acridine inhibits Salmonella enterica growth}

Various small molecules that either stabilized or destabilized the G-quadruplexes conformations are being under investigation for therapeutic intervention of various human pathogenic infection such as BRACO-19, TMPyP4, and several 9-amino acridine derivatives[42]. Previously, 9-amino acridine and its derivatives have been observed for their anti-proliferative properties in cancer cells [53] by binding to the telomeric region [54], the c-Myc gene [55] and c-Kit promoter [56]. Therefore, here we were interested in analyzing the effect of 9-amino acridine on the $S$. enterica growth and performed agar disc diffusion assay and MTT assay. A clear zone of inhibition was observed in the agar plate comparable to ampicillin and penicillin (S4 Fig) that suggested the inhibitory effect of 9-amino acridine on the S. enterica growth and an MTT assay observed an $\mathrm{IC}_{50}$ value of $10.5 \mu \mathrm{M}$ (Fig 7).

\section{9-amino acridine stabilized the SE-PGQs and thereby stalls the movement of polymerase}

In order to understand the role of SE-PGQs in the cytotoxic effect of 9-amino acridine, binding affinity of 9-amino acridine with these SE-PGQs were analyzed by performing CD Melting studies. An increase in the melting temperature $\left(\Delta \mathrm{T}_{\mathrm{m}} \sim 8.5^{\circ} \mathrm{C}\right)$ was observed upon addition of 9-amino acridine when compared with alone SE-PGQs. This indicated that 9-amino acridine increased the thermodynamic stability of SE- 
PGQs (Fig 8). Further, we employed a Taq polymerase PCR stop assay to investigate whether 9-amino acridine complex formation with SE-PGQs, make it possible to stop the movement of polymerase replication machinery or not. In order to investigate this hypothesis, we incubated PCR reaction mixture with 9-amino acridine in a concentration dependent manner and then performed PCR amplification. We observed diminished intensity of bands with increase in concentration of 9-amino acridine, however, in the absence of the 9 amino acridine the band intensity was maximum indicated that the Taq polymerase were able to extend the SE-PGQs motifs. It shows that binding of the 9-amino acridine to the SE-PGQs motif stabilized the G-quadruplex structure and inhibited the movement of replication machinery over the untreated SE-PGQs. On the contrary, when mutant PGQs lacking G-tract were used as a DNA template, 9-amino acridine was not able to bind and thus, could not inhibit the movement of Taq polymerase and produced a PCR product in the reaction(Fig 9).

\section{9-amino acridine decreases the transcription rate of the genes harboring PGQs:}

Further, we performed qRT-PCR assay to check the effect of 9-amino acridine on the expression of the PGQs harboring genes. The gene transcripts of the genes were quantified with respect to 16 s rRNA gene and the fold change in the expression of the transcripts was analyzed for the treated cells in comparison to non-treated cell (control culture). The qRT-PCR analysis revealed the presence of the 9 amino acridine reduced the rate of transcription of $m g t A$, entA and malK by $1.86,3.03$ and 2.94 fold respectively. malE gene showed the highest suppression by 7.16 fold decrease in its expression in the presence of 9 amino acridine. In conclusion, all the four genes showed decrease in the expression level, thus strengthening the G4 medicated inhibition mechanism in the their promoter/regulator or open reading frame region (Fig 10)

\section{Discussion}

Salmonella enterica is a food-borne pathogenic bacterium and causes a spectrum of diseases including enteric fever (typhoid) and food poisoning in human(2). Global burden of $S$. enterica is rising exponentially due to the emergence of multidrug and extremely resistant strains. Therefore, it becomes essential to develop a novel therapeutic strategy that can work in both drug susceptible and drug- 
resistant strain infection of this deadly bacterium and it could only be possible if a conserved drug target available in all strains of this bacterium could be targeted. Recently, conserved G-quadruplexes and their binding with small molecule are being extensively investigated as a promising therapeutic approach for combating the various type of human pathogen infection[42, 46]. For example, HIV-1 promoter region possessed a G-quadruplex motif in long terminal repeat (LTR) region of their genome and observed to be critical for its proliferation. BRACO-19 has shown anti-HIV-1 activity by stabilizing G-quadruplex motif present in the LTR region[42]. Similarly, stabilization of G-quadruplex structure present in the core gene of HCV genome by PDP, halts its replication, translation and therefore can be used as potential antihepatitis therapeutics[57]. Pyridostatin is also observed to stabilize the G-quadruplex structure formed in the mRNA of nuclear antigen 1 protein of EBV leading to its translation suppression[58]. Recently, BRACO-19 and quarfloxin have shown inhibitory effect on Mycobacterium tuberculosis and Plasmodium falciparum by stabilizing G-quadruplexes present in various regions of their genome[40, 59].

Considering the suitability of G-quadruplex structure as a promising drug target in both drug susceptible and drug-resistant strain of pathogens, here we sought to search for G-quadruplex motifs in S. enterica strains. The bioinformatics analysis gave a boost to our hypothesis as we received an ample number of potential G-quadruplex motifs in the genome of S. enterica strains. Interestingly three Gquadruplex forming motifs were found to be conserved in $\geq 98 \%$ strains of Salmonella enterica and present in three different locations namely i) SE-PGQ-1 in the regulatory region of $m g t A$, ii) SE-PGQ-2 in open reading frame of entA gene. iii) and SE-PGQ-3 in the regulatory region shared by maltose operon genes: malK, and malE gene.1D ${ }^{1} \mathrm{H}$ NMR spectroscopy was used to confirm the formation of $\mathrm{G}$ quadruplex structure by all SE-PGQs whereas EMSA demonstrated the intramolecular G-quadruplex structure formation by SE-PGQs. CD spectroscopy was used to confirm the topology of SE-PGQs in solution. Taken together, the NMR, CD, and EMSA results allow us to conclude that the SE-PGQ-1 and SE-PGQ-3 motifs form intramolecular parallel G-quadruplex structures whereas SE-PGQ-2 form intramolecular mixed type of G-quadruplex structures.

Similar to G-quadruplex motif present in genome of another human pathogen, a G-quadruplex motif present in $m g t A$, malK, malE and entA genes of $\mathrm{S}$. enterica strains may also serve as a potential 
target for developing anti-bacterial therapy. These G-rich targets can also overcome the problem of the drug resistance due to their high conservedness in both drug-susceptible and drug-resistant bacterial strains. Since these PGQs were present in the promoter region of $m g t A$, malE and malK and the open reading frame of entA gene, we explore the stabilizing effect of 9-amino acridine on SE-PGQs. Firstly, CD melting analysis revealed the increased thermos-stability of the SE-PGQs by exhibiting an increase in their melting temperature $\left(T_{m}\right)$ in the presence of the 9 amino acridine. The observed $\Delta T_{m}$ values were observed as $6.94{ }^{\circ} \mathrm{C}, 10.98{ }^{\circ} \mathrm{C}$ and $8.78{ }^{\circ} \mathrm{C}$ for SE-PGQ-1, SE-PGQ-2, and SE-PGQ-3 respectively. Further, binding of 9-amino acridine to SE-PGQs reveled the stallation of the movement of DNA replication machinery across G4 motifs. Next, we evaluated the inhibitory effect of 9-amino acridine on S. enterica growth; $\mathrm{IC}_{50}$ value was calculated to be $10.50 \mu \mathrm{M}$. Highly stable G-quadruplexes in the regulatory regions and open reading frame of genes were previously shown to down-regulate the expression of genes [60-62]. The treatment of $S$. enterica cultures with 9-amino acridine led to a decrease in the expression of entA, mgtA, malK and MalE genes relative to $16 \mathrm{~S}$ rRNA, suggesting a G-quadruplex mediated inhibition mechanism is involved in this process. As a schematic model elaborated in Fig 11, Gquadruplex mediated inhibition of entA, $m g t A$, malK and MalE genes is expected to increase the innate immune response of host cell and reduced survival of bacterium inside the host cell. The Inhibited expression of the entA and $m g t A$ proteins would make the bacteria unable to response against Reactive oxygen/nitrogen (ROS/RNS)species and reduced their survival inside the host macrophages.

As a concluding remark, the current study shows the presence of stable and highly conserved Gquadruplex structures in essential genes of Salmonella enterica. The 9-amino acridine were observed to bind and reduced the expression of these G-quadruplex structure possessing genes and thereby proposed as novel G4 mediated therapeutic approach for combating the infection of Salmonella enterica in humans. 


\section{Materials and methods}

\section{Prediction, conserved motif enrichment and functional analysis of G-quadruplex motifs in Salmonella enterica strains}

Completely sequenced strains of S. enterica (S1 Table) were downloaded from National Center for Biotechnology Information (NCBI). These strains were then extensively mined for the potential Gquadruplex motifs in both sense and antisense strand using our previously developed G-quadruplex predictor tool[63]. This prediction tools used the following regular expression.

$$
\mathbf{G}_{\{\mathrm{T} 1\}}[\mathbf{X}]_{\{L 1\}} \mathbf{G}_{\{\mathrm{T} 1\}}[\mathbf{X}]_{\{\mathrm{L} 2\}} \mathbf{G}_{\{\mathrm{T} 1\}}[\mathbf{X}]_{\{\mathrm{L} 3\}} \mathbf{G}_{\{\mathrm{T} 1\}}
$$

Where T1 represents consecutive tracts of Guanine that can be any number from $2-7, \mathrm{X}$ is any nucleotide $(A, T, G, C), L 1, L 2, L 3$ represents the variable loop region and can be any number from 1-7. For our prediction, we used G-tracts -3 or 4 and loop length 1-20 nucleotide [63]. The results were further cross verified by using QGRS Mapper[64] and PGSFinder[65] tools.

To find the conserved PGQ's that are available in all the strains, multiple sequence alignment (MSA) was performed by using Clustal Omega tool and clustering was done using UPGMA method. Consensus sequences representing the whole G4 sequence with -5 and +5 flanking regions were constructed using the Glam2 tool of MEME Suite[66].

The resultant PGQ clusters were then mapped for their gene location in the genome of the individual S. enterica strains using the coordinates extracted from our G4 prediction tool by using Graphics mode of GenBank Database (https://www.ncbi.nlm.nih.gov/nuccore/).

\section{Salmonella genus $\mathbf{G} 4$ homolog prediction}

In order to check the conservation of predicted PGQs at the Salmonella genus level, NCBI nucleotide BLAST was performed by taking each consensus PGQ as a query sequence and Salmonella bongori genome sequences as a target(NCBI taxid: 590$)$. The threshold e-value was set as $1 \mathrm{e}-3$ to remove any results by chance. 


\section{Oligonucleotide preparation for CD and ITC analysis}

Predicted G4 oligonucleotides sequences were procured from Sigma Aldrich Chemicals Ltd. (St. Louis, MO, USA). $100 \mu \mathrm{M}$ stock solutions were prepared as per manufacturer's instructions. Before each set of experiment, oligonucleotides were subjected to re-anneal by heating at $95{ }^{\circ} \mathrm{C}$ for 10 minutes and slow cooling at room temperature for $2 \mathrm{hrs}$. All these oligonucleotides were dissolved in four different Trisbuffer $(\mathrm{pH}=7.0,10 \mathrm{mM})$ containing $50 \mathrm{mM}$ of $\mathrm{K}^{+}, \mathrm{Na}^{+}$, $\mathrm{Li}^{+}$and $\mathrm{Mg}^{2+}$ separately.

\section{Spectroscopy and melting analysis}

$\mathrm{CD}$ experiments were performed for each oligonucleotide in different buffer conditions at $25^{\circ} \mathrm{C}$ with the scanning rate of $20 \mathrm{~nm} / \mathrm{min}$ from 220 to $320 \mathrm{~nm}$ using Jasco J-185 Spectropolarimeter (Jasco Hachioji, Tokyo, Japan). The instrument was equipped with Peltier Junction temperature controller. Spectra were recorded in a cuvette of $1 \mathrm{~mm}$ path length for a final concentration of $20 \mu \mathrm{M}$ of all oligonucleotides in Tris buffer $(10 \mathrm{mM}, \mathrm{pH}=7.4)$ containing four different cations viz. $\mathrm{K}^{+}, \mathrm{Na}^{+}, \mathrm{Mg}^{2+}$ and $\mathrm{Li}^{+}(50 \mathrm{mM}$ each) in separate experiments. To avoid signal contribution from the buffer, a blank spectrum was recorded before each measurement and subtracted from CD spectrum of the sample prepared in respective buffer.

CD Melting analysis was performed for every PGQs with a temperature range of $25^{\circ} \mathrm{C}$ to $98^{\circ} \mathrm{C}$ in four different cations $\left(\mathrm{K}^{+}, \mathrm{Na}^{+}, \mathrm{Mg}^{2+}\right.$ and $\mathrm{Li}^{+}, 50 \mathrm{mM}$ each) containing buffers. The heating rate was set as $1^{\circ} \mathrm{C} / \mathrm{min}$ for each melting experiments

\section{Electrophoretic Mobility Shift assay}

Native PAGE was run using $20 \%$ polyacrylamide gel in 1 X TBE buffer. Each sample was dissolved in Tris buffer $(\mathrm{pH}=7,10 \mathrm{mM})$ containing four different cations $\mathrm{K}^{+}, \mathrm{Na}^{+}, \mathrm{Mg}^{2+}, \mathrm{Li}^{+}(50 \mathrm{mM}$ each) separately. For each PGQ, an oligonucleotide of similar length ( $G$ mutated with $T$ nucleotide) was taken as a negative control, and standard G-quadruplex (Tel22 DNA) was taken as a positive control. $20 \mu \mathrm{l}$ of each oligonucleotide sample were loaded, and electrophoresis was performed at $4^{\circ} \mathrm{C}, 90$ Voltage in a vertical gel unit system. The gels were visualized by staining with ethidium bromide and analyzed on ImageQuant LAS 4000 gel doc (GE Healthcare Biosciences Ltd., Sweden).). 


\section{One dimensional ${ }^{1} \mathrm{H}-\mathrm{NMR}$ Spectroscopy}

AVANCE $500 \mathrm{MHz}$ BioSpin International AG, Switzerland equipped with a $5 \mathrm{~mm}$ broadband inverse probe was used to perform NMR spectroscopic analysis. All the NMR experiments were performed using $\mathrm{H}_{2} \mathrm{O} / \mathrm{D}_{2} \mathrm{O}$ solvent at 9:1 ratio. Temperature of $298 \mathrm{~K}$ with $20 \mathrm{ppm}$ spectral width and 3 - (Trimethylsilyl) propionic-2, 2, 3, 3-D4 acid sodium salt (TSP) as an internal reference were used. NMR data processing, integration, and analysis were done by using Topspin 1.3 software.

\section{Bacterial strain culture and growth conditions}

The S. ser. Typhimurium strain ATCC 14028 was procured from HiMedia and streaked on Nutrient Agar (HiMedia). A single colony was inoculated in the in Nutrient Broth (HiMedia) and kept overnight at $37^{\circ} \mathrm{C}$ and $220 \mathrm{rpm}$ in incubator shaker.

\section{Growth inhibition assay - Disk Diffusion and MTT}

Disk diffusion method was employed to identify the susceptibility of bacteria to 9- amino acridine. For the antimicrobial activity of 9-amino acridine to $S$. enterica, the overnight growth culture was spread onto the Nutrient Agar plate. Whatman paper disks soaked with 9-amino acridine solution (in DMSO) containing 20 $\mu \mathrm{g}, 10 \mu \mathrm{g}$, and $5 \mu \mathrm{g}$ placed onto the plates spread with S. enterica. Penicillin and Streptomycin (HiMedia) standard disk of $10 \mu \mathrm{g}$ were used as positive control while the solvent, DMSO was used as a negative control. The plates were incubated at $37^{\circ} \mathrm{C}$ for 16 hours, followed by measurement of the zone of inhibition [67].

MTT assay was performed for cytotoxic analysis of 9-amino acridine on S. enterica. $50 \mu \mathrm{l}$ of the overnight grown culture of $S$. enterica, was inoculated in $5 \mathrm{ml}$ Nutrient Broth (NB) at $220 \mathrm{rpm}, 37^{\circ} \mathrm{C}$ and allowed to grow till the $O . D_{600}=0.5$. After that, $50 \mu \mathrm{l}$ was transferred in fresh $5 \mathrm{ml}$ NB tube and $100 \mu \mathrm{l}$ was transferred in each well of 96 well plate. Dilution was prepared from the stock solution $(200 \mu \mathrm{M})$ of 9amino acridine of the following concentrations $100 \mu \mathrm{M}-0.09 \mu \mathrm{M}$ and added to the respective wells, last well served as blank (without 9-amino acridine). The plates were kept at $37^{\circ} \mathrm{C}, 220 \mathrm{rpm}$ for $3 \mathrm{hr}$. Afterward, $10 \mu \mathrm{l}$ of MTT $(5 \mathrm{mg} / \mathrm{mL})$ was added to each well and incubated for $3 \mathrm{hr}$. Finally, $20 \mu \mathrm{l}$ of DMSO was added in each well to dissolve formazan crystal, and the plate was examined using microplate reader (BioTek) at $590 \mathrm{~nm}[68]$. 


\section{PCR Stop Assay}

Templates and Primers were procured from Sigma-Aldrich Chemicals Ltd. (St. Louis, MO, USA) (Table S5a). The reaction was performed in the master mix consisting of $1 \mathrm{X}$ PCR buffer, $0.33 \mathrm{mM}$ dNTPs, $2 \mu \mathrm{M}$ templated, $2 \mu \mathrm{M}$ reverse primer, 2.5 units Taq DNA polymerase (Sigma-Aldrich Chemicals Ltd. St. Louis, MO, USA) and a dose titration of 9-amino acridine. The following thermal cycling conditions were used: initial denaturation at $95{ }^{\circ} \mathrm{C}$ for $5 \mathrm{~min}$, followed by 25 cycles of $95^{\circ} \mathrm{C}$ for $30 \mathrm{~s}, 50{ }^{\circ} \mathrm{C}$ for $30 \mathrm{~s}, 72{ }^{\circ} \mathrm{C}$ for 0.5 minute and finally held at $4{ }^{\circ} \mathrm{C}$. The $6 \mathrm{X}$ DNA loading dye was added to the amplified products and resolved in 3\% agarose gel. Ethidium bromide was used for staining and gel images were analyzed using ImageQuant LAS 4000 (GE Healthcare, Biosciences Ltd.,Sweden).

\section{Total RNA isolation and cDNA synthesis}

S. enterica was grown overnight at $37^{\circ} \mathrm{C}, 220 \mathrm{rpm}$ in $5 \mathrm{ml}$ of test tube containing NB. Two flasks of $500 \mathrm{ml}$ containing $50 \mathrm{ml}$ of NB each were inoculated with $1 \%$ inoculum from overnight culture. Both the flasks of untreated and treated cells were allowed to grow according to previously mentioned condition till the O. $D_{600} \mathrm{~nm}$ reached 0.5. At O. $\mathrm{D}_{600}=0.5,10.35 \mu \mathrm{M}$ of 9-amino acridine were added to MIC flask. For control culture DMSO was added as 9-amino acridine was dissolved in it. All the flasks were kept at $37^{\circ} \mathrm{C}$, $220 \mathrm{rpm}$ for $45 \mathrm{~min}$. Subsequently, samples were centrifuged at $12000 \mathrm{rpm}$ and immediately preceded for RNA isolation. S. enterica culture prior to RNA isolation was treated with RNA protect reagent (Qiagen, USA) to stabilize RNA and prevent it from degradation. Treated and untreated Salmonella cultures were used for total RNA isolation. RNA isolation for all samples was carried out using TRIZOL reagent (Invitrogen) according to manufacturer's instructions. After RNA isolation, its concentration and purity was measured using NanoDrop (Thermoscientific) as ng/ul and A260/A280, respectively. Subsequently, all the RNA samples were treated with RNase-free DNasel (Invitrogen) as mentioned by the manufacturer. Finally, $5 \mu \mathrm{g}$ of total RNA from each sample were used for cDNA synthesis. CDNA synthesis was performed in a $20 \mu \mathrm{l}$ reaction by using Invitrogen Superscript IV kit (Cat \# 18091050) according to the manufactures instruction. 


\section{Gene Expression Profiling Using Real-Time quantitative PCR}

Quantitative Real-Time PCR was used to elucidate the variation in gene expression profiling of Salmonella treated with 9-amino acridine. All the aliquots of cDNA from untreated (control) and treated (9amino acridine) were used in real time PCR. qPCR was carried out in PCR master reaction mix containing 1x PowerUp ${ }^{\mathrm{TM}}$ SYBR尺 Green Master Mix (Applied Biosystem, USA), $0.5 \mu \mathrm{M}$ of each primer and $11 \mu \mathrm{l}$ of cDNA sample in a final reaction volume of $25 \mu \mathrm{l}$ in a 96 well PCR plate in Step One Plus (Applied Biosystem, USA) Thermal Cycler. All the samples for real time were analyzed in three dilutions and duplicates, normalization was done with respect to 16s rRNA (housekeeping gene). The proportionate change in genes expression was assessed by change in expression of target gene in treated as compared to control. List of primers used in real time PCR and thermo-cycling conditions are mentioned in Supplementary Table S5b and Supplementary Table S5c, respectively. Briefly, the thermocycle used in qRT-PCR was $94^{\circ} \mathrm{C}$ for 2 min, subsequently 40 cycles of $94^{\circ} \mathrm{C}$ for $15 \mathrm{sec}$ and $57^{\circ} \mathrm{C}$ for 1 $\min$.

\section{AVAILABILITY}

Putative G-quadruplex prediction tool is an open web-based tool to predict putative G- quadruplexforming sequences in different nucleotide stretches.

(http://bsbe.iiti.ac.in/bsbe/ipdb/pattern2.php)

\section{Authors Contribution}

Data conceptualization and methodology was performed by A.K. Bioinformatics analysis was done by S.K.M., N.J., and U.S. Biophysical analysis was performed by S.K.M., N.J., U.S.. S.K.M. N.J. and A.J. performed MTT assay. A.J., S.K.M. and N.J. performed RT-PCR under the supervision of P.K. and A.K.. N.J., S.K.M. and A.T. wrote the manuscript. A.K. T.K.S. and P.K. did the review and editing.

\section{Acknowledgment:}

The authors are thankful to SIC Facility at IIT Indore for NMR and CD experiments. 


\section{Conflict of interest}

The authors declare no conflict of interest.

\section{References}

1. Echeita MA, Aladuena A, Cruchaga S, Usera MA. Emergence and spread of an atypical Salmonella enterica subsp. enterica serotype 4,5,12:i:- strain in Spain. Journal of clinical microbiology. 1999;37(10):3425. Epub 1999/09/17. PubMed PMID: 10488227; PubMed Central PMCID: PMCPMC85594.

2. Brenner FW, Villar RG, Angulo FJ, Tauxe R, Swaminathan B. Salmonella Nomenclature. Journal of Clinical Microbiology. 2000;38(7):2465-7. PubMed PMID: PMC86943.

3. Gal-Mor O, Boyle EC, GrassI GA. Same species, different diseases: how and why typhoidal and non-typhoidal Salmonella enterica serovars differ. Frontiers in Microbiology. 2014;5(391). doi: 10.3389/fmicb.2014.00391.

4. Mandilara G, Vassalos CM, Chrisostomou A, Karadimas K, Mathioudaki E, Georgakopoulou T. A severe gastroenteritis outbreak of Salmonella enterica serovar Enteritidis PT8, with PFGE profile Xbal.0024 and MLVA profile 2-9-7-3-2 following a christening reception, Greece, 2016. 2018;146(1):2836. doi: 10.1017/s0950268817002667. PubMed PMID: 29198195.

5. Bloomfield SJ, Benschop J, Biggs PJ, Marshall JC, Hayman DTS, Carter PE, et al. Genomic Analysis of Salmonella enterica Serovar Typhimurium DT160 Associated with a 14-Year Outbreak, New Zealand, 1998-2012. Emerging infectious diseases. 2017;23(6):906-13. Epub 2017/05/19. doi: 10.3201/eid2306.161934. PubMed PMID: 28516864; PubMed Central PMCID: PMCPmc5443446.

6. Anderson TC, Marsden-Haug N, Morris JF, Culpepper W, Bessette N, Adams JK, et al. Multistate Outbreak of Human Salmonella Typhimurium Infections Linked to Pet Hedgehogs - United States, 20112013. Zoonoses and public health. 2017;64(4):290-8. Epub 2016/10/14. doi: 10.1111/zph.12310. PubMed PMID: 27734610.

7. Muvhali M, Smith AM, Rakgantso AM, Keddy KH. Investigation of Salmonella Enteritidis outbreaks in South Africa using multi-locus variable-number tandem-repeats analysis, 2013-2015. BMC infectious diseases. 2017;17(1):661. Epub 2017/10/04. doi: 10.1186/s12879-017-2751-8. PubMed PMID: 28969587; PubMed Central PMCID: PMCPmc5625639.

8. Allard MW, Bell R, Ferreira CM, Gonzalez-Escalona N, Hoffmann M, Muruvanda T, et al. Genomics of foodborne pathogens for microbial food safety. Current opinion in biotechnology. 2017;49:224-9. Epub 2017/11/24. doi: 10.1016/j.copbio.2017.11.002. PubMed PMID: 29169072.

9. Crump JA, Luby SP, Mintz ED. The global burden of typhoid fever. Bulletin of the World Health Organization. 2004;82(5):346-53. Epub 2004/08/10. PubMed PMID: 15298225; PubMed Central PMCID: PMCPmc2622843.

10. Varma JK, Molbak K, Barrett TJ, Beebe JL, Jones TF, Rabatsky-Ehr T, et al. Antimicrobial-resistant nontyphoidal Salmonella is associated with excess bloodstream infections and hospitalizations. The Journal of infectious diseases. 2005;191(4):554-61. Epub 2005/01/19. doi: 10.1086/427263. PubMed PMID: 15655779.

11. Omulo S, Thumbi SM, Njenga MK, Call DR. A review of 40 years of enteric antimicrobial resistance research in Eastern Africa: what can be done better? Antimicrobial Resistance and Infection Control. 2015;4(1):1. doi: 10.1186/s13756-014-0041-4.

12. Karkey A, Thwaites GE, Baker S. The evolution of antimicrobial resistance in Salmonella Typhi. Current opinion in gastroenterology. 2018;34(1):25-30. 
13. Eng S-K, Pusparajah P, Ab Mutalib N-S, Ser H-L, Chan K-G, Lee L-H. Salmonella: a review on pathogenesis, epidemiology and antibiotic resistance. Frontiers in Life Science. 2015;8(3):284-93.

14. Mearin F, Perez-Oliveras M, Perello A, Vinyet J, Ibanez A, Coderch J, et al. Dyspepsia and irritable bowel syndrome after a Salmonella gastroenteritis outbreak: one-year follow-up cohort study. Gastroenterology. 2005;129(1):98-104. Epub 2005/07/14. PubMed PMID: 16012939.

15. Townes JM. Reactive arthritis after enteric infections in the United States: the problem of definition. Clinical infectious diseases : an official publication of the Infectious Diseases Society of America. 2010;50(2):247-54. Epub 2009/12/23. doi: 10.1086/649540. PubMed PMID: 20025528. 16. Jones TF, Ingram LA, Cieslak PR, Vugia DJ, Tobin-D'Angelo M, Hurd S, et al. Salmonellosis outcomes differ substantially by serotype. The Journal of infectious diseases. 2008;198(1):109-14. Epub 2008/05/09. doi: 10.1086/588823. PubMed PMID: 18462137.

17. Buzby JC, Roberts T. The economics of enteric infections: human foodborne disease costs. Gastroenterology. 2009;136(6):1851-62. Epub 2009/05/22. doi: 10.1053/j.gastro.2009.01.074. PubMed PMID: 19457414.

18. Ploton MC, Gaschignard J, Lemaitre C, Cadennes A, Germanaud D, Poncelet G, et al. Salmonella Typhimurium bacteraemia complicated by meningitis and brain abscess in a 3-month-old boy. Journal of paediatrics and child health. 2017;53(2):204-5. Epub 2017/02/15. doi: 10.1111/jpc.13433. PubMed PMID: 28194898.

19. Hakim S, Davila F, Amin M, Hader I, Cappell MS. Infectious Aortitis: A Life-Threatening Endovascular Complication of Nontyphoidal Salmonella Bacteremia. Case Reports in Medicine. 2018;2018.

20. Chamnongpol S, Groisman EA. Mg2+ homeostasis and avoidance of metal toxicity. Mol Microbiol. 2002;44(2):561-71. Epub 2002/04/26. PubMed PMID: 11972791.

21. O'Connor K, Fletcher SA, Csonka LN. Increased expression of $\mathrm{Mg}(2+)$ transport proteins enhances the survival of Salmonella enterica at high temperature. Proceedings of the National Academy of Sciences of the United States of America. 2009;106(41):17522-7. doi: 10.1073/pnas.0906160106. PubMed PMID: PMC2765158.

22. Bourret TJ, Liu L, Shaw JA, Husain M, Vazquez-Torres A. Magnesium homeostasis protects Salmonella against nitrooxidative stress. Sci Rep. 2017;7(1):15083. Epub 2017/11/10. doi: 10.1038/s41598-017-15445-y. PubMed PMID: 29118452; PubMed Central PMCID: PMCPmc5678156.

23. Sattely ES, Fischbach MA, Walsh CT. Total biosynthesis: in vitro reconstitution of polyketide and nonribosomal peptide pathways. Natural product reports. 2008;25(4):757-93. Epub 2008/07/30. doi: 10.1039/b801747f. PubMed PMID: 18663394.

24. Raymond KN, Dertz EA, Kim SS. Enterobactin: An archetype for microbial iron transport. Proceedings of the National Academy of Sciences of the United States of America. 2003;100(7):3584-8. doi: 10.1073/pnas.0630018100. PubMed PMID: PMC152965.

25. Crouch ML, Castor M, Karlinsey JE, Kalhorn T, Fang FC. Biosynthesis and IroC-dependent export of the siderophore salmochelin are essential for virulence of Salmonella enterica serovar Typhimurium. Mol Microbiol. 2008;67(5):971-83. Epub 2008/01/16. doi: 10.1111/j.1365-2958.2007.06089.x. PubMed PMID: 18194158.

26. Achard ME, Chen KW, Sweet MJ, Watts RE, Schroder K, Schembri MA, et al. An antioxidant role for catecholate siderophores in Salmonella. The Biochemical journal. 2013;454(3):543-9. Epub 2013/06/29. doi: 10.1042/bj20121771. PubMed PMID: 23805839.

27. Lun S, Guo H, Adamson J, Cisar JS, Davis TD, Chavadi SS, et al. Pharmacokinetic and in vivo efficacy studies of the mycobactin biosynthesis inhibitor salicyl-AMS in mice. Antimicrob Agents Chemother. 2013;57(10):5138-40. Epub 2013/07/17. doi: 10.1128/aac.00918-13. PubMed PMID: 23856770; PubMed Central PMCID: PMCPmc3811451. 
28. Balhara M, Chaudhary R, Ruhil S, Singh B, Dahiya N, Parmar VS, et al. Siderophores; iron scavengers: the novel \& promising targets for pathogen specific antifungal therapy. Expert opinion on therapeutic targets. 2016;20(12):1477-89. Epub 2016/11/01. doi: 10.1080/14728222.2016.1254196. PubMed PMID: 27797604.

29. Stirrett KL, Ferreras JA, Jayaprakash V, Sinha BN, Ren T, Quadri LE. Small molecules with structural similarities to siderophores as novel antimicrobials against Mycobacterium tuberculosis and Yersinia pestis. Bioorganic \& medicinal chemistry letters. 2008;18(8):2662-8. Epub 2008/04/09. doi: 10.1016/j.bmcl.2008.03.025. PubMed PMID: 18394884; PubMed Central PMCID: PMCPmc2430880. 30. Imperi F, Massai F, Facchini M, Frangipani E, Visaggio D, Leoni L, et al. Repurposing the antimycotic drug flucytosine for suppression of Pseudomonas aeruginosa pathogenicity. Proceedings of the National Academy of Sciences of the United States of America. 2013;110(18):7458-63. Epub 2013/04/10. doi: 10.1073/pnas.1222706110. PubMed PMID: 23569238; PubMed Central PMCID: PMCPmc3645532.

31. Lamb AL. Breaking a pathogen's iron will: Inhibiting siderophore production as an antimicrobial strategy. Biochimica et biophysica acta. 2015;1854(8):1054-70. Epub 2015/05/15. doi: 10.1016/j.bbapap.2015.05.001. PubMed PMID: 25970810; PubMed Central PMCID: PMCPmc4457648. 32. Daus ML, Grote M, Schneider E. The MalF P2 loop of the ATP-binding cassette transporter MalFGK2 from Escherichia coli and Salmonella enterica serovar typhimurium interacts with maltose binding protein (MalE) throughout the catalytic cycle. Journal of bacteriology. 2009;191(3):754-61. 33. Vikram A, Jayaprakasha GK, Jesudhasan PR, Pillai SD, Patil BS. Obacunone represses Salmonella pathogenicity islands 1 and 2 in an envZ-dependent fashion. Applied and environmental microbiology. 2012;78(19):7012-22.

34. Huppert JL. Four-stranded nucleic acids: structure, function and targeting of G-quadruplexes. Chemical Society reviews. 2008;37(7):1375-84. Epub 2008/06/24. doi: 10.1039/b702491f. PubMed PMID: 18568163.

35. Largy E, Marchand A, Amrane S, Gabelica Vr, Mergny J-L. Quadruplex turncoats: cationdependent folding and stability of quadruplex-DNA double switches. Journal of the American Chemical Society. 2016;138(8):2780-92.

36. Balasubramanian S, Neidle S. G-quadruplex nucleic acids as therapeutic targets. Current opinion in chemical biology. 2009;13(3):345-53.

37. Gatto B, Palumbo M, Sissi C. Nucleic acid aptamers based on the G-quadruplex structure: therapeutic and diagnostic potential. Current medicinal chemistry. 2009;16(10):1248-65.

38. Murat $P$, Balasubramanian S. Existence and consequences of $G$-quadruplex structures in DNA. Current opinion in genetics \& development. 2014;25:22-9. Epub 2014/03/04. doi: 10.1016/j.gde.2013.10.012. PubMed PMID: 24584093.

39. Rawal P, Kummarasetti VB, Ravindran J, Kumar N, Halder K, Sharma R, et al. Genome-wide prediction of G4 DNA as regulatory motifs: role in Escherichia coli global regulation. Genome research. 2006;16(5):644-55. Epub 2006/05/03. doi: 10.1101/gr.4508806. PubMed PMID: 16651665; PubMed Central PMCID: PMCPMC1457047.

40. Calvo EP, Wasserman M. G-Quadruplex ligands: Potent inhibitors of telomerase activity and cell proliferation in Plasmodium falciparum. Molecular and biochemical parasitology. 2016;207(1):33-8. Epub 2016/05/25. doi: 10.1016/j.molbiopara.2016.05.009. PubMed PMID: 27217226.

41. Griffin BD, Bass HW. Review: Plant G-quadruplex (G4) motifs in DNA and RNA; abundant, intriguing sequences of unknown function. Plant science : an international journal of experimental plant biology. 2018;269:143-7. Epub 2018/04/03. doi: 10.1016/j.plantsci.2018.01.011. PubMed PMID: 29606212.

42. Ruggiero E, Richter SN. G-quadruplexes and G-quadruplex ligands: targets and tools in antiviral therapy. Nucleic acids research. 2018;46(7):3270-83. doi: 10.1093/nar/gky187. 
43. Rhodes D, Lipps HJ. G-quadruplexes and their regulatory roles in biology. Nucleic acids research. 2015;43(18):8627-37. Epub 2015/09/10. doi: 10.1093/nar/gkv862. PubMed PMID: 26350216; PubMed Central PMCID: PMCPmc4605312.

44. Bidzinska J, Cimino-Reale G, Zaffaroni N, Folini M. G-quadruplex structures in the human genome as novel therapeutic targets. Molecules (Basel, Switzerland). 2013;18(10):12368-95. Epub 2013/10/11. doi: 10.3390/molecules181012368. PubMed PMID: 24108400.

45. Simone R, Fratta P, Neidle S, Parkinson GN, Isaacs AM. G-quadruplexes: emerging roles in neurodegenerative diseases and the non-coding transcriptome. FEBS letters. 2015;589(14):1653-68.

46. Harris LM, Merrick CJ. G-quadruplexes in pathogens: a common route to virulence control? PLoS pathogens. 2015;11(2):e1004562.

47. Guillon J, Cohen A, Das RN, Boudot C, Gueddouda NM, Moreau S, et al. Design, synthesis, and antiprotozoal evaluation of new 2, 9-bis [(substituted-aminomethyl) phenyl]-1, 10-phenanthroline derivatives. Chemical biology \& drug design. 2018;91(5):974-95.

48. Beaume N, Pathak R, Yadav VK, Kota S, Misra HS, Gautam HK, et al. Genome-wide study predicts promoter-G4 DNA motifs regulate selective functions in bacteria: radioresistance of $D$. radiodurans involves G4 DNA-mediated regulation. Nucleic acids research. 2013;41(1):76-89. Epub 2012/11/20. doi: 10.1093/nar/gks1071. PubMed PMID: 23161683; PubMed Central PMCID: PMCPmc3592403.

49. Waller ZA, Pinchbeck BJ, Buguth BS, Meadows TG, Richardson DJ, Gates AJ. Control of bacterial nitrate assimilation by stabilization of G-quadruplex DNA. Chemical communications (Cambridge, England). 2016;52(92):13511-4. Epub 2016/11/03. doi: 10.1039/c6cc06057a. PubMed PMID: 27805200; PubMed Central PMCID: PMCPmc5123632.

50. Burge S, Parkinson GN, Hazel P, Todd AK, Neidle S. Quadruplex DNA: sequence, topology and structure. Nucleic acids research. 2006;34(19):5402-15. Epub 2006/10/03. doi: 10.1093/nar/gkl655. PubMed PMID: 17012276; PubMed Central PMCID: PMCPMC1636468.

51. Vorlickova M, Kejnovska I, Sagi J, Renciuk D, Bednarova K, Motlova J, et al. Circular dichroism and guanine quadruplexes. Methods (San Diego, Calif). 2012;57(1):64-75. Epub 2012/03/28. doi: 10.1016/j.ymeth.2012.03.011. PubMed PMID: 22450044.

52. Oganesian L, Moon IK, Bryan TM, Jarstfer MB. Extension of G-quadruplex DNA by ciliate telomerase. The EMBO journal. 2006;25(5):1148-59. Epub 2006/03/03. doi: 10.1038/sj.emboj.7601006. PubMed PMID: 16511573; PubMed Central PMCID: PMCPmc1409729.

53. Ferreira R, Avino A, Mazzini S, Eritja R. Synthesis, DNA-binding and antiproliferative properties of acridine and 5-methylacridine derivatives. Molecules. 2012;17(6):7067-82. Epub 2012/06/12. doi: 10.3390/molecules17067067. PubMed PMID: 22683895.

54. Harrison RJ, Cuesta J, Chessari G, Read MA, Basra SK, Reszka AP, et al. Trisubstituted acridine derivatives as potent and selective telomerase inhibitors. Journal of medicinal chemistry. 2003;46(21):4463-76. Epub 2003/10/03. doi: 10.1021/jm0308693. PubMed PMID: 14521409.

55. Liao SR, Zhou CX, Wu WB, Ou TM, Tan JH, Li D, et al. 12-N-Methylated 5,6-

dihydrobenzo[c]acridine derivatives: a new class of highly selective ligands for c-myc G-quadruplex DNA. European journal of medicinal chemistry. 2012;53:52-63. Epub 2012/04/20. doi:

10.1016/j.ejmech.2012.03.034. PubMed PMID: 22513122.

56. Guo QL, Su HF, Wang N, Liao SR, Lu YT, Ou TM, et al. Synthesis and evaluation of 7-substituted5,6-dihydrobenzo[c]acridine derivatives as new c-KIT promoter G-quadruplex binding ligands. European journal of medicinal chemistry. 2017;130:458-71. Epub 2017/03/12. doi: 10.1016/j.ejmech.2017.02.051. PubMed PMID: 28284084.

57. Wang SR, Min YQ. A highly conserved G-rich consensus sequence in hepatitis C virus core gene represents a new anti-hepatitis C target. 2016;2(4):e1501535. doi: 10.1126/sciadv.1501535. PubMed PMID: 27051880. 
58. Murat P, Zhong J, Lekieffre L, Cowieson NP, Clancy JL, Preiss T, et al. G-quadruplexes regulate Epstein-Barr virus-encoded nuclear antigen 1 mRNA translation. Nature chemical biology. 2014;10(5):358-64. Epub 2014/03/19. doi: 10.1038/nchembio.1479. PubMed PMID: 24633353; PubMed Central PMCID: PMCPMC4188979.

59. Perrone R, Lavezzo E, Riello E, Manganelli R, Palu G. Mapping and characterization of Gquadruplexes in Mycobacterium tuberculosis gene promoter regions. 2017;7(1):5743. doi: 10.1038/s41598-017-05867-z. PubMed PMID: 28720801.

60. Endoh T, Kawasaki Y, Sugimoto N. Suppression of gene expression by G-quadruplexes in open reading frames depends on G-quadruplex stability. Angewandte Chemie (International ed in English). 2013;52(21):5522-6. Epub 2013/04/17. doi: 10.1002/anie.201300058. PubMed PMID: 23589400.

61. Wang SR, Zhang QY, Wang JQ, Ge XY, Song YY, Wang YF, et al. Chemical Targeting of a GQuadruplex RNA in the Ebola Virus L Gene. Cell chemical biology. 2016;23(9):1113-22. Epub 2016/09/13. doi: 10.1016/j.chembiol.2016.07.019. PubMed PMID: 27617851.

62. Endoh T, Kawasaki Y, Sugimoto N. Stability of RNA quadruplex in open reading frame determines proteolysis of human estrogen receptor alpha. Nucleic Acids Res. 2013;41(12):6222-31. Epub 2013/04/27. doi: 10.1093/nar/gkt286. PubMed PMID: 23620292; PubMed Central PMCID: PMCPmc3695533.

63. Mishra SK, Tawani A, Mishra A, Kumar A. G4IPDB: A database for G-quadruplex structure forming nucleic acid interacting proteins. Scientific reports. 2016;6:38144. Epub 2016/12/03. doi: 10.1038/srep38144. PubMed PMID: 27905517; PubMed Central PMCID: PMCPmc5131279.

64. Kikin O, D'Antonio L, Bagga PS. QGRS Mapper: a web-based server for predicting G-quadruplexes in nucleotide sequences. Nucleic Acids Res. 2006;34(Web Server issue):W676-82. Epub 2006/07/18. doi: 10.1093/nar/gkI253. PubMed PMID: 16845096; PubMed Central PMCID: PMCPmc1538864.

65. Hon J, Martinek T, Zendulka J, Lexa M. pqsfinder: an exhaustive and imperfection-tolerant search tool for potential quadruplex-forming sequences in R. Bioinformatics (Oxford, England). 2017;33(21):3373-9. Epub 2017/10/28. doi: 10.1093/bioinformatics/btx413. PubMed PMID: 29077807. 66. Bailey TL, Boden M, Buske FA, Frith M, Grant CE, Clementi L, et al. MEME SUITE: tools for motif discovery and searching. Nucleic acids research. 2009;37(Web Server issue):W202-8. Epub 2009/05/22. doi: 10.1093/nar/gkp335. PubMed PMID: 19458158; PubMed Central PMCID: PMCPmc2703892.

67. Valgas C, Souza SMd, Smânia EF, Smânia Jr A. Screening methods to determine antibacterial activity of natural products. Brazilian Journal of Microbiology. 2007;38(2):369-80.

68. Wang J, Liu H, Zhao J, Gao H, Zhou L, Liu Z, et al. Antimicrobial and antioxidant activities of the root bark essential oil of Periploca sepium and its main component 2-hydroxy-4-methoxybenzaldehyde. Molecules. 2010;15(8):5807-17.

\section{Figure Captions and Legends}

Fig 1. Salmonella genus classification and G-quadruplex topologies.

a) Flowchart depicting the classification of the Salmonella genus. b) G-quartet structure showing hoogsteen hydrogen bond formation between Guanines and cation binding. c) Different types of topologies formed by intermolecular and intramolecular G-quadruplex structures.

Fig 2. mgtA, entA and maltose operon mediated mechanisms. 
Schematic representation of the functions related with a) $m g t A$. b) entA and c) maltose operon mediated mechanisms in growth and virulence of Salmonella enterica.

Fig 3. Representation and localization of three highly conserved PGQs.

a) Diagrammatic representation of SE-PGQ-1 harbored at upstream of $m g t A$, SE-PGQ-2 in the open reading frame of entA gene, and SE-PGQ-3 in intergenic regulatory region of malK and malE in the Salmonella enterica genome. b) Details of three most conserved PGQs including location, Gene id, Gene locus, G-quadruplex strand and gene direction in the reference genome of Salmonella enterica (CT18 strain). c) Consensus Sequence of the most conserved PGQs predicted by Glam2 tool of MEME Suite.

\section{Fig 4. NMR Spectra.}

1D ${ }^{1} \mathrm{H}$ NMR spectra of SE-PGQ-1(mgtA), SE-PGQ-2(entA), SE-PGQ-3(malE and malK) in the presence of $\mathrm{K}^{+}$Buffer

\section{Fig 5. Circular Dichorism Analysis.}

a) Circular Dichroism spectra of the three most conserved PGQs in the presence of Tris-Cl buffer (10 $\mathrm{mM}$ ) containing either of $50 \mathrm{mM} \mathrm{K}^{+}$(red), $50 \mathrm{mM} \mathrm{Na}^{+}$(green), $50 \mathrm{mM} \mathrm{Li}^{+}$(yellow), $50 \mathrm{mM} \mathrm{Mg}^{2+}$ (blue) or mut of the same length(Pink). b) Melting spectra obtained by Circular Dichroism in different buffers $\left(\mathrm{K}^{+}\right.$, $\mathrm{Na}^{+}, \mathrm{Li}^{+}$and $\mathrm{Mg}^{2+}$ ) for conserved PGQs predicted in Salmonella enterica. In the absence of any buffer(Black), $\mathrm{K}^{+} 50 \mathrm{mM}\left(\right.$ Red), $\mathrm{K}^{+} 200 \mathrm{mM}$ (Green), $\mathrm{Na}^{+} 50 \mathrm{mM}$ (Yellow), $\mathrm{Li}^{+} 50 \mathrm{mM}$ (Blue)and $\mathrm{Mg}^{2+}$ 50mM (Pink). c) Bar-graph depicting Tm of SE-PGQ-1(mgtA), SE-PGQ-2(entA), SE-PGQ-3(malE and malK) in the absence and presence of various cations.

Fig 6. Electrophoretic Mobility Shift assay.

Gel images of the SE-PGQ-1(mgtA), SE-PGQ-2(entA), and SE-PGQ-3(malE and malK). Lane 1: Mutant (Primer of equal length of the PGQ; Lane 2: $\mathrm{PGQ}$ in $\mathrm{K}^{+}$buffer; Lane 3: PGQ in $\mathrm{Na}^{+}$buffer; Lane 4: PGQ in $\mathrm{Li}^{+}$buffer and Lane 5: PGQ in $\mathrm{Mg}^{2+}$ buffer; Lane 6: Mutant (Primer of equal length of the predicted PGQ). Lane7: Positive control (Tel22 G-quadruplex); Lane 8: Negative control (mutant primer of equal length of the Tel22 G-quadruplex sequence) 
Fig 7. Growth inhibition (MTT) assay of Salmonella enterica.

a) Dose dependent growth curve of Salmonella enterica treated with 9-amino acridine. b) Growth inhibition of Salmonella enterica in the presence of various concentrations of the 9-amino acridine

Fig 8. Interaction of 9-amino acridine with SE-PGQs.

Circular Dichroism melting curve depicting the change in $\mathrm{T}_{m}$ of SE-PGQ-1(mgtA), SE-PGQ-2(entA), and SE-PGQ-3(malE and malK) in the presence and absence of 9-amino acridine.

\section{Fig 9. PCR Stop assay.}

Gel image of Taq Polymerase stop assay for SE-PGQ-1(mgtA), SE-PGQ-2(entA), and SE-PGQ-3(malE and $m a / K)$ and linear DNA with the increasing concentrations of 9-amino acridine

\section{Fig 10. RT-qPCR.}

The normalized fold change of $m g t A$, entA, malE and malK transcripts in Salmonella enterica determined by quantitative PCR in the absence (culture control) and presence of 9-amino acridine(treated).

Fig 11. Effect of 9-amino acridine on $m g t A$, entA and maltose operon mediated mechanisms.

Schematic representation of G-quadruplex loci and the effect of their stabilization with 9-amino acridine on the survival and virulence of Salmonella enterica.

\section{Supplementary Files captions and Legends}

S1 File. G-quadruplex prediction.

List of G-quadruplexes predicted in 412 strains of Salmonella enterica with G-tract 3 and 4 with loop length 0 to $20 \mathrm{bp}$.(Excel file)

S2 File. Cluster of highly conserved SE-PGQs in the Salmonella enterica strains.

Position of SE-PGQ-1(mgtA), SE-PGQ-2(entA) and SE-PGQ-3(malE and malK) in the strains of Salmonella enterica genome. (Excel file) 
S1 Fig. NMR Spectra of 15 PGQs conserved in more than $90 \%$ strains of Salmonella enterica.

1D $1 \mathrm{H}$ NMR Spectra of PGQs conserved in $\geq 90 \%$ (SE-PGQ-4 to SE-PGQ-18) in $\mathrm{K}^{+}$buffer.(TIFF file)

S2 Fig. CD Spectra of 15 PGQs conserved in more than $90 \%$ strains of Salmonella enterica.

Circular Dichroism spectra of SE-PGQ-4 to SE-PGQ-18 in Tris-Cl buffer (10 mM) containing either $50 \mathrm{mM}$ $\mathrm{KCl}$ (red), $50 \mathrm{mM} \mathrm{NaCl}$ (green), $50 \mathrm{mM} \mathrm{LiCl}$ (yellow) or $50 \mathrm{mM} \mathrm{MgCl}$ (blue). (TIFF file)

S3 Fig. CD Spectra with increasing concentration of $\mathrm{K}^{+}$ion.

Circular Dichroism spectra of the most conserved PGQs in the absence of any cation or in the presence of $50 \mathrm{mM} \mathrm{K}^{+}$(Green), $100 \mathrm{mM} \mathrm{K}^{+}$(Yellow), $150 \mathrm{mM} \mathrm{K}^{+}$(Blue), or $200 \mathrm{mM} \mathrm{K}^{+}$(Pink). (TIFF file)

\section{S4 Fig. Agar Disc diffusion assay.}

Zone of inhibition obtained by agar disc diffusion assay for 20, 10 and $5 \mu$ g of 9-amino acridine against Salmonella enterica. (TIFF file)

S1 Table. Salmonella enterica strains used in the analysis.

List of Salmonella enterica strains taken into consideration for our analysis with their genome IDs.(Word file)

S2 Table. Conserved G-quadruplex in Salmonella enterica.

Complete list of G-quadruplexes in Salmonella enterica conserved in more than $90 \%$ of strains with Gtract $3 / 4$ and loop length 0 to $20 \mathrm{bp}$. (Word file)

S3 Table: Conserved G-quadruplex prediction using QGRSMapper and PQSFinder.

a). G4 prediction of conserved PGQ's using QGRS mapper tool. b). G4 prediction of conserved PGQ's using PGSFinder tool. (Word file)

S4 Table. Mutants for CD analysis.

List of mutant sequence used for Circular Dichroism analysis. (Mutated A is highlighted with red) (Word file)

S5 Table. Primer List. 
bioRxiv preprint doi: https://doi.org/10.1101/357046; this version posted June 27, 2018. The copyright holder for this preprint (which was not certified by peer review) is the author/funder, who has granted bioRxiv a license to display the preprint in perpetuity. It is made available under aCC-BY 4.0 International license.

a) List of primers used for Taq polymenrase stop assay. b) List of primers used in RT-PCR. c) List of parameters used for thermal cycling conditions used for RT-PCR assay. (Word file) 

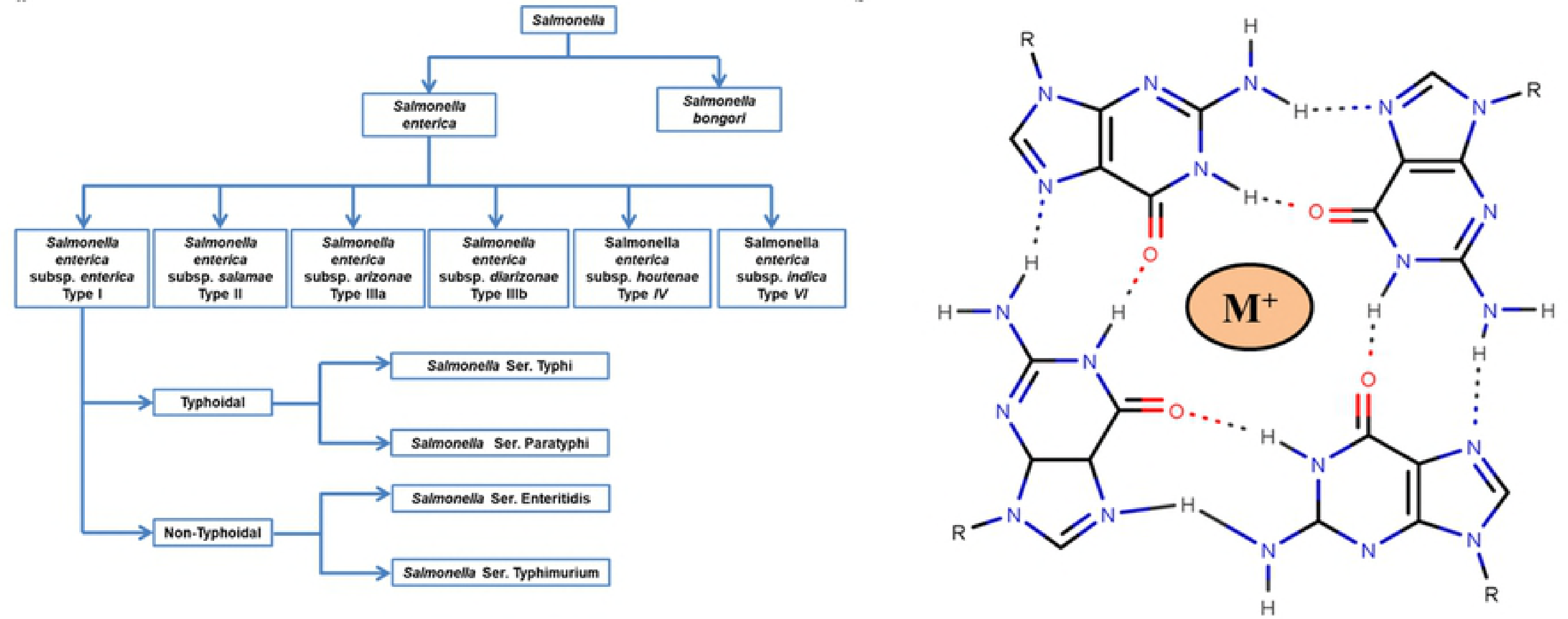

c

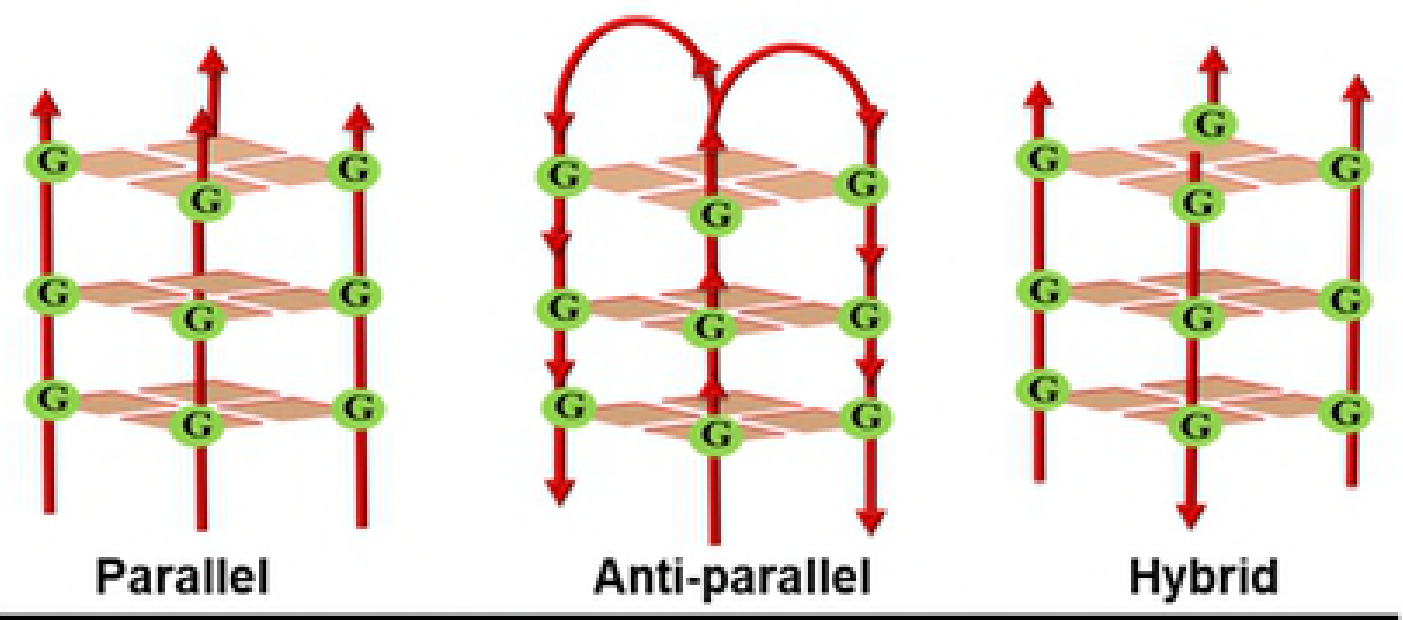

Intermolecular G-Quadruplex

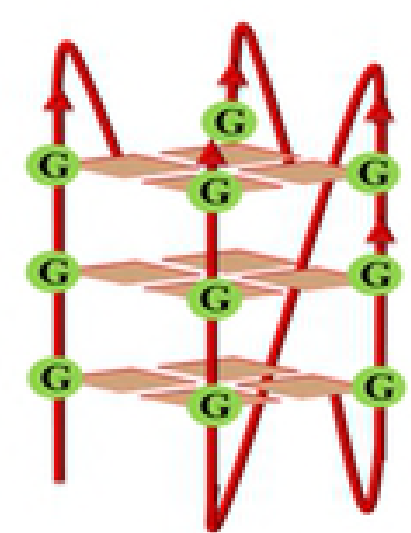

Parallel

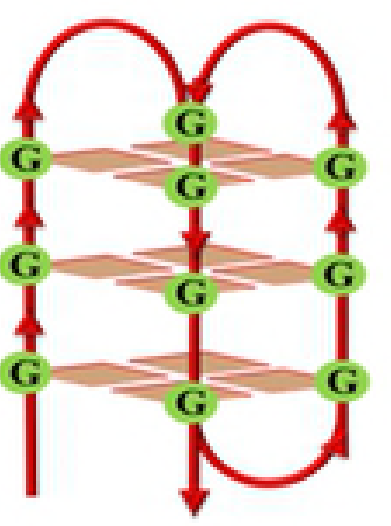

Anti-parallel

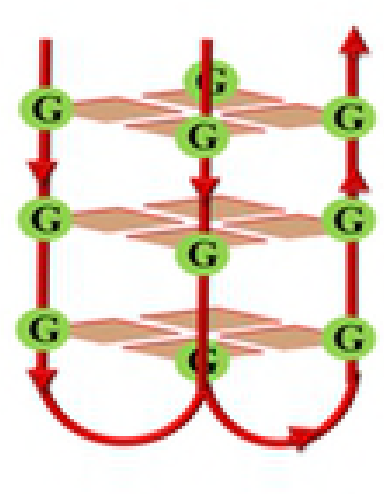

Hybrid 


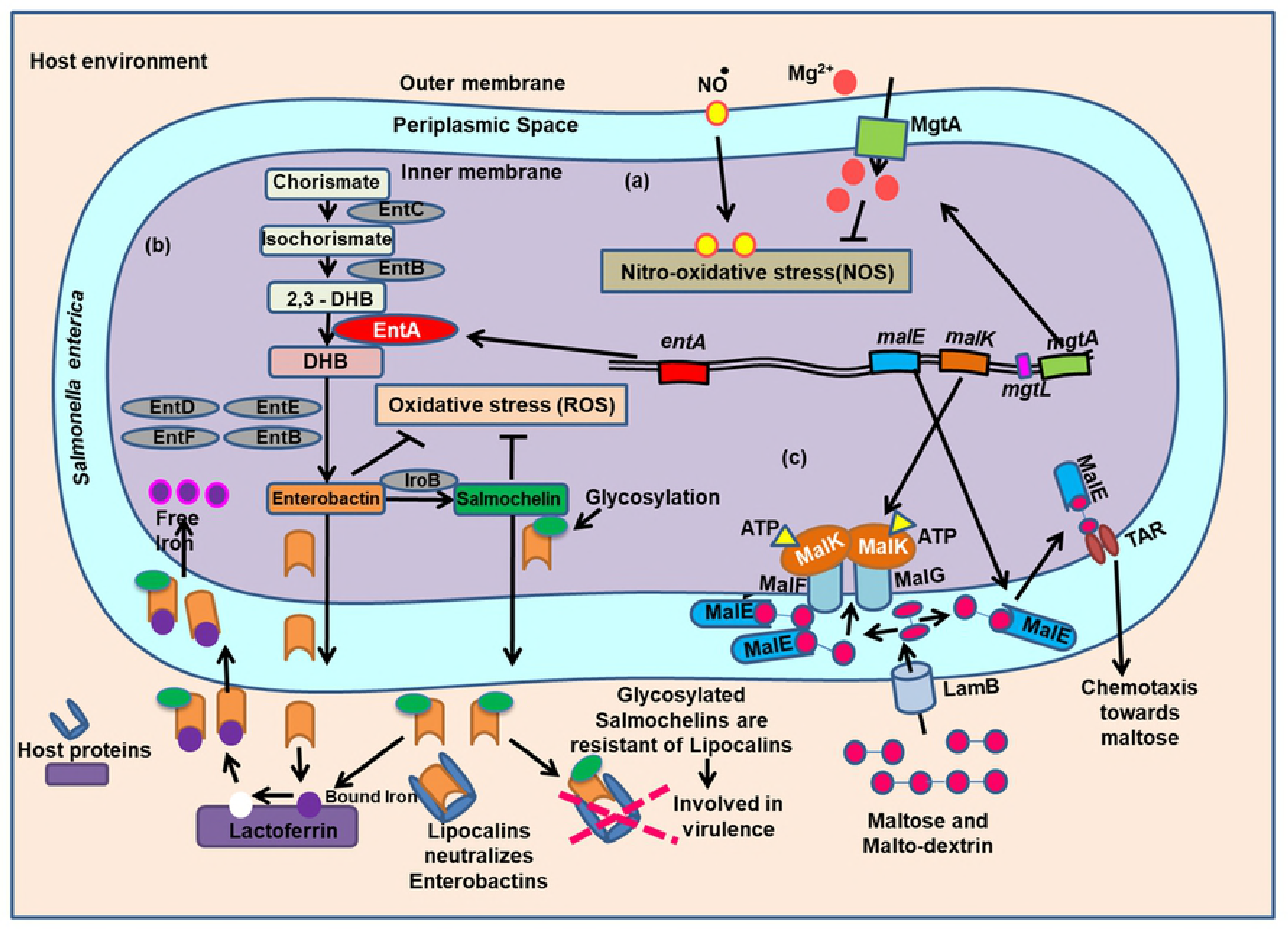




\section{SE-PGQ-3 ( $m a l E$ and $m a / K$ )}

\section{SE-PGQ-2 (entA)}

SE-PGQ-1 (mgtA) 

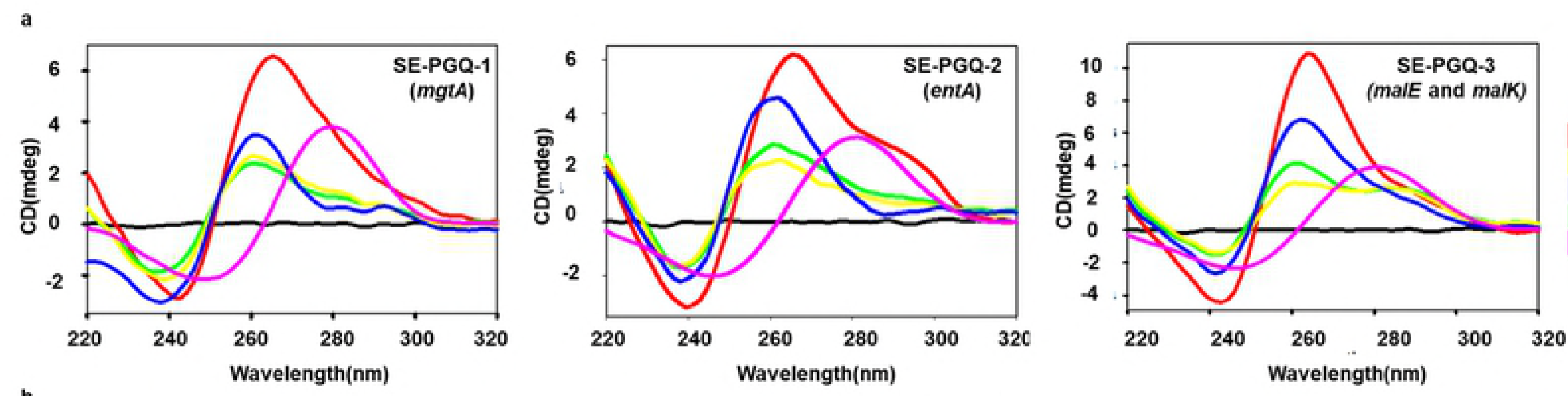

$\mathrm{K}^{*}(50 \mathrm{mM})$ $\mathrm{Na}^{+}(50 \mathrm{mM})$

$\mathrm{Mg}^{2+}(50 \mathrm{mM})$

$\mathrm{Li}^{+}(50 \mathrm{mM})$

$\operatorname{mut}\left(\mathrm{K}^{+}=50 \mathrm{mM}\right)$
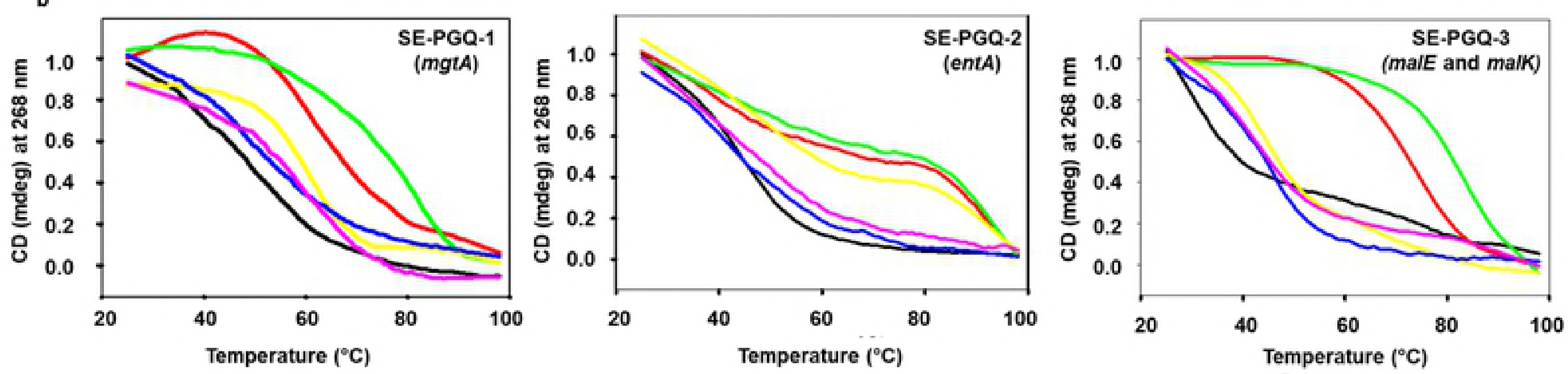

$\mathrm{K}^{+}(200 \mathrm{mM})$

$\mathrm{K}^{+}(50 \mathrm{mM})$

$\mathrm{Na}^{*}(50 \mathrm{mM})$

$\mathrm{Mg}^{2+}(50 \mathrm{mM})$

$\mathrm{Li}^{+}(50 \mathrm{mM})$

KCL (0mM)

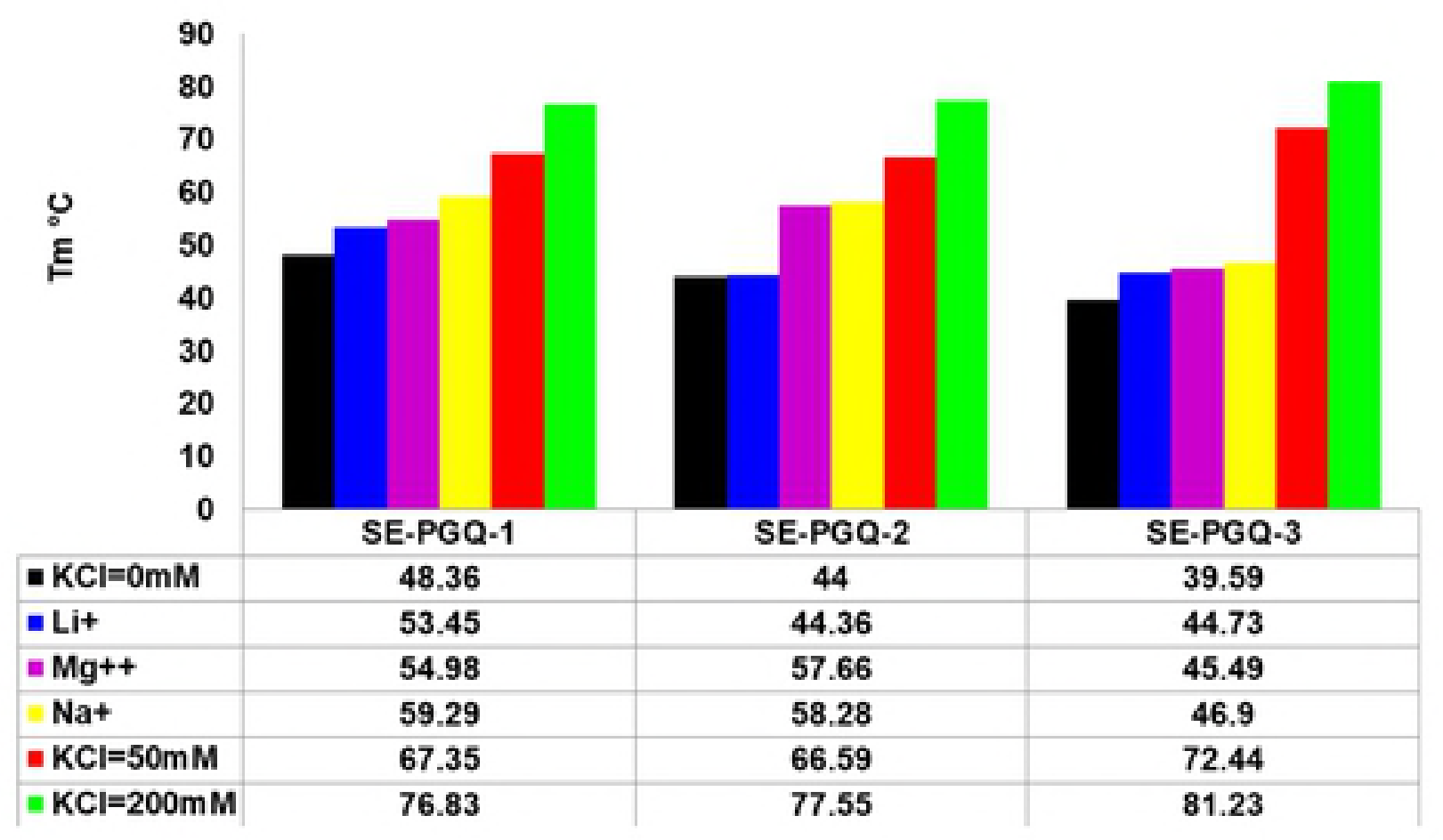


$\begin{array}{llllllll}1 & 2 & 3 & 4 & 5 & 6 & 7 & 8\end{array}$

SE-PGQ-1

(mgtA)

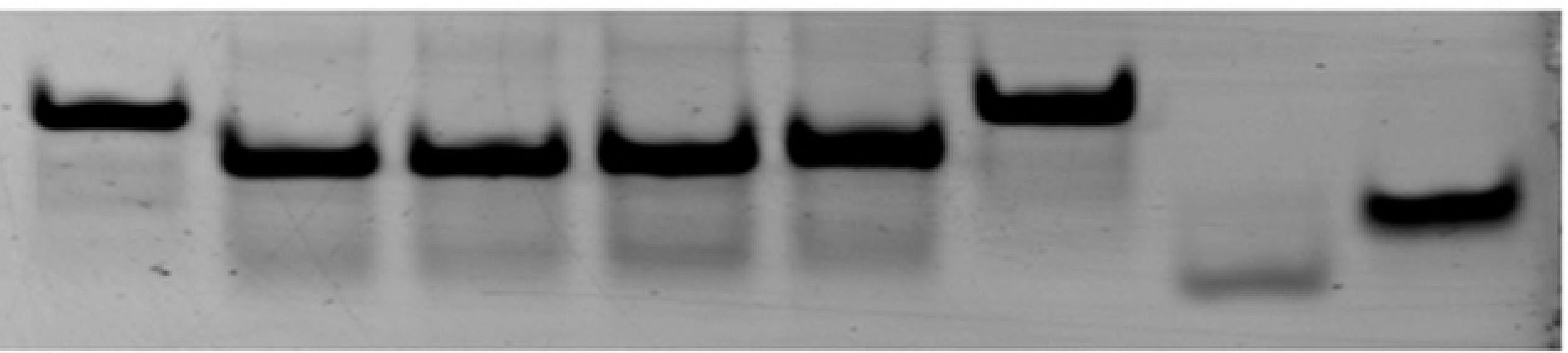

$\begin{array}{llllllll}1 & 2 & 3 & 4 & 5 & 6 & 7 & 8\end{array}$

SE-PGQ-2

(entA)

SE-PGQ-3

( $m a l E$ and $m a / K$ )
1
2
3
45
6
7
8 
$\begin{array}{ll}\mathbf{a} & \mathbf{b}\end{array}$
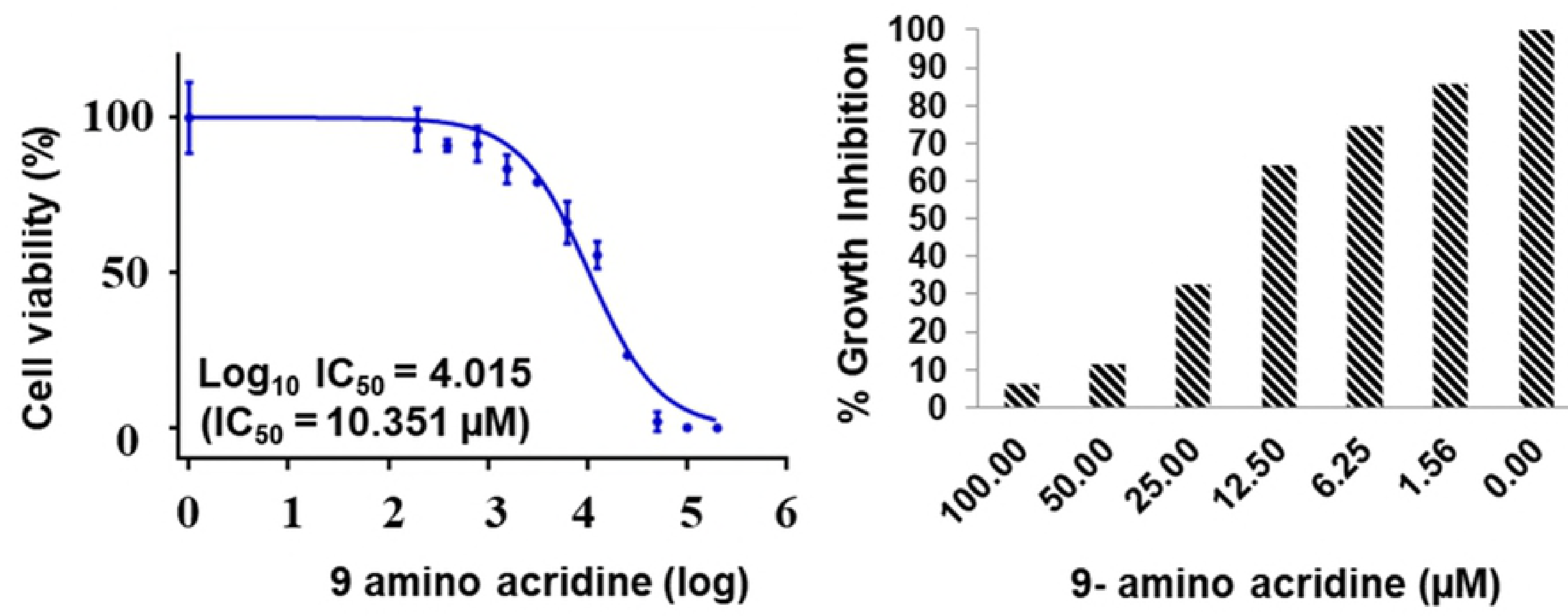

9- amino acridine $(\mu \mathrm{M})$ 
Molar ratio $(r)=0.0$

Molar ratio $(r)=2.0$
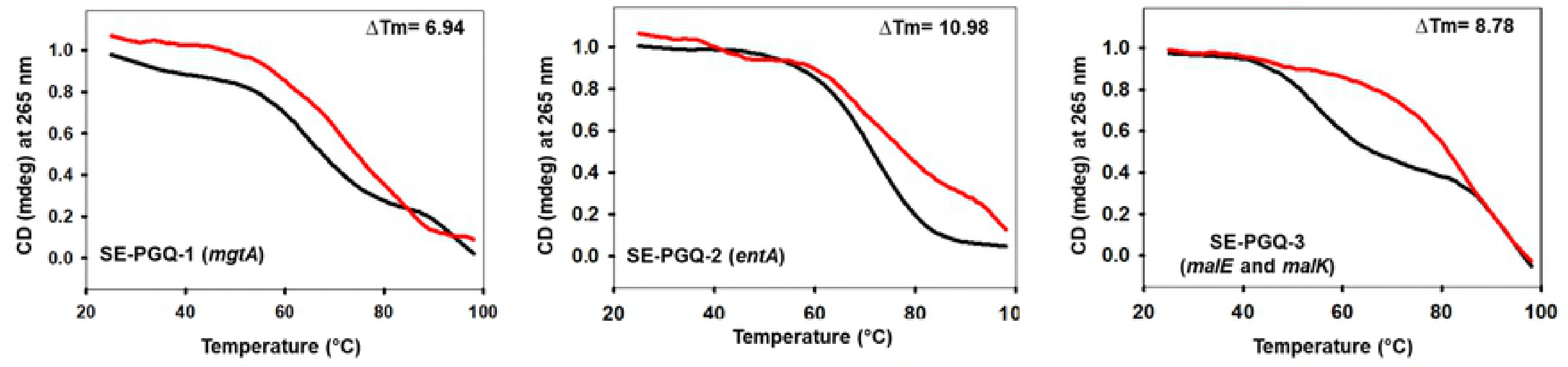

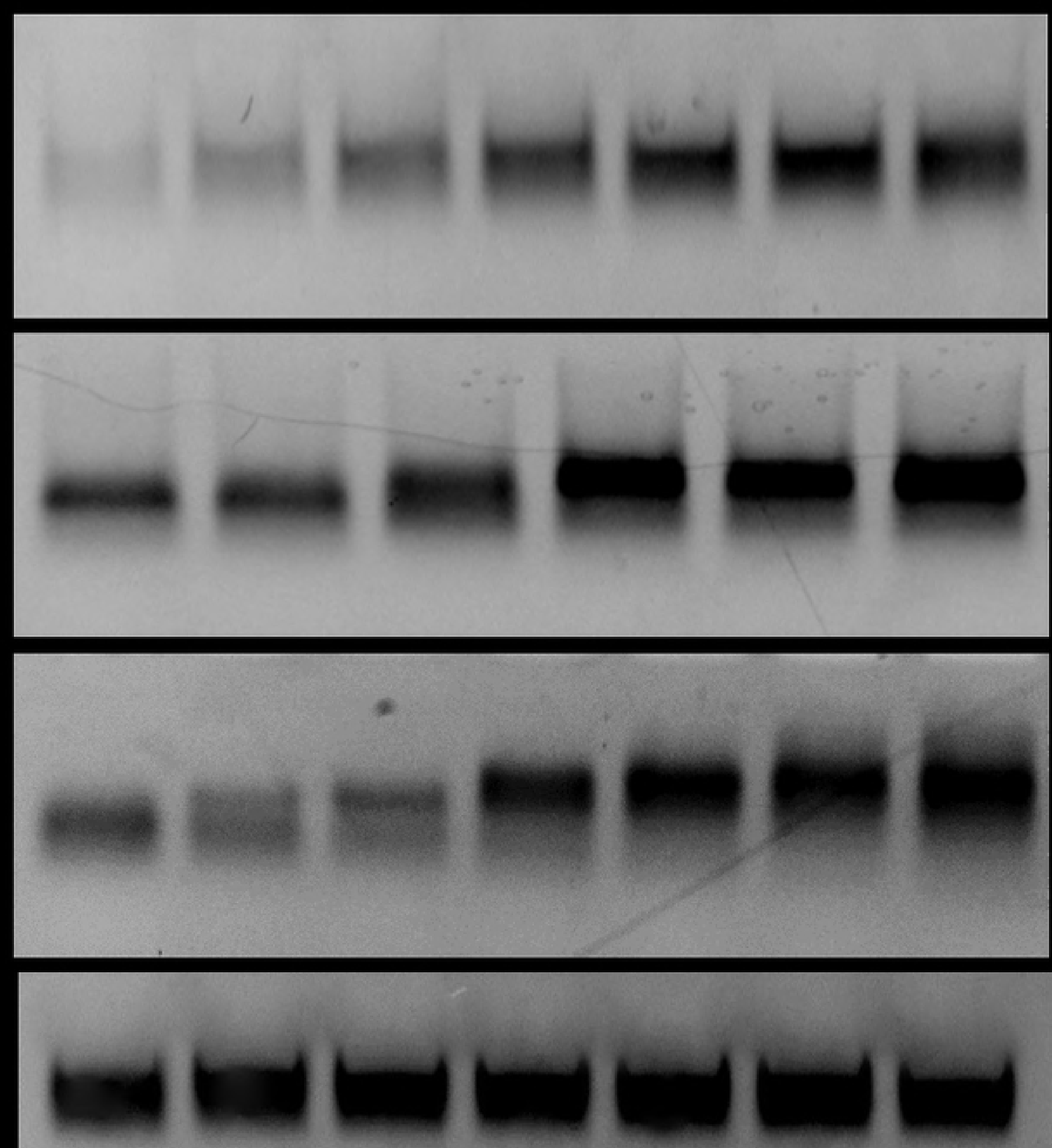


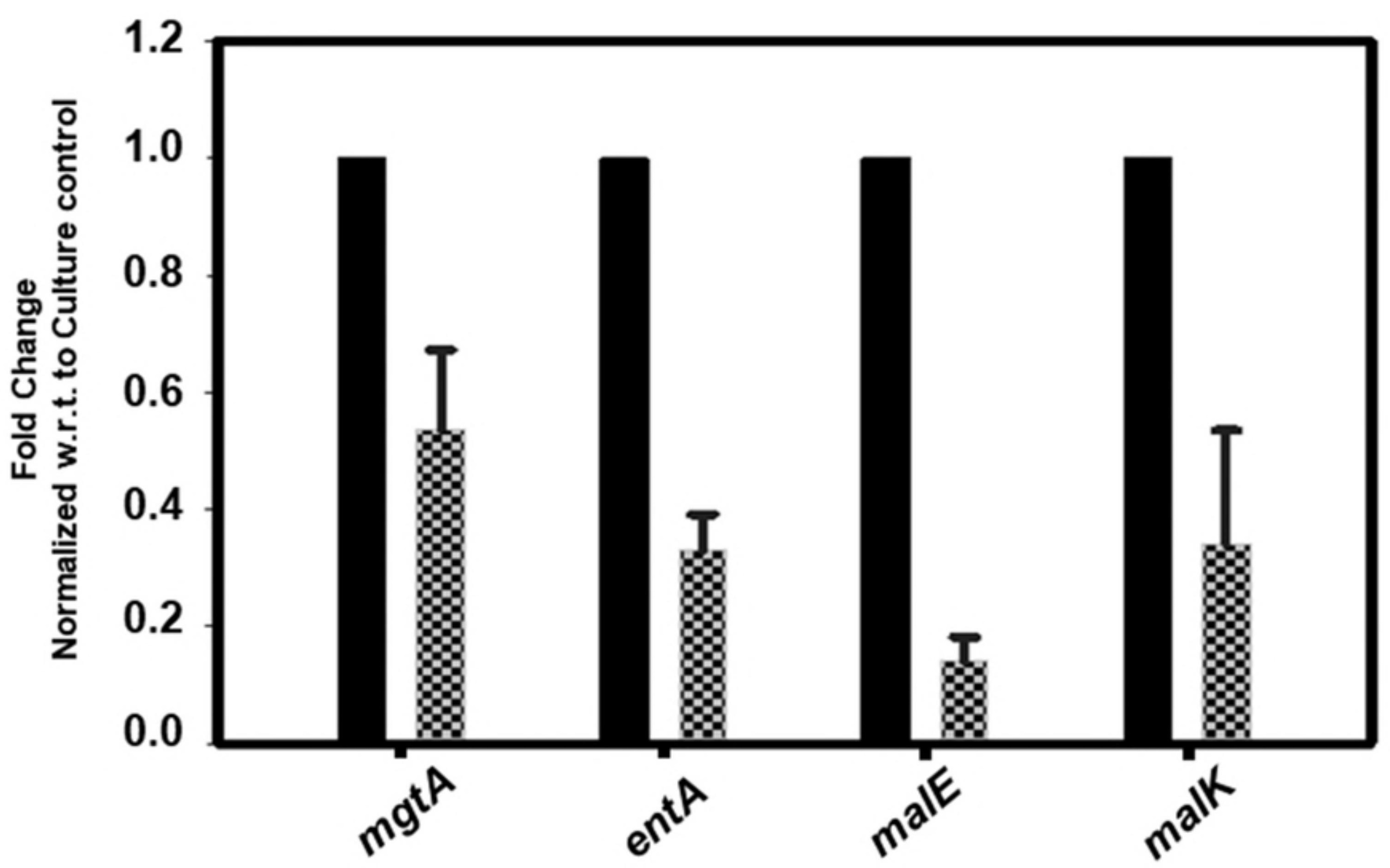



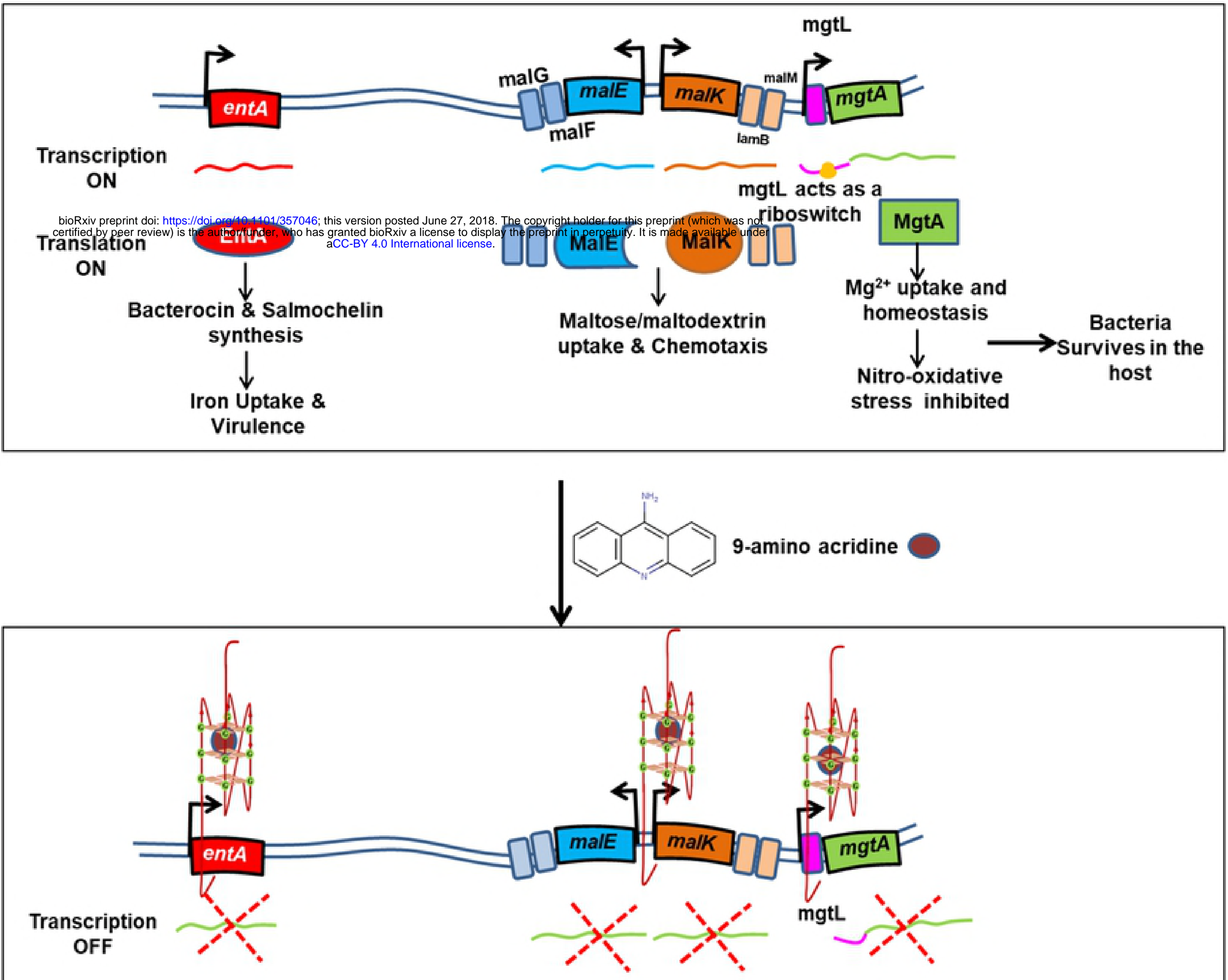

Translation OFF

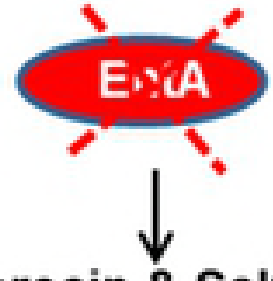

Bacterocin \& Salmochelin synthesis is blocked<smiles>C=[V]</smiles>
Iron Uptake inhibited

\& Virulence is reduced

9-amino acridine
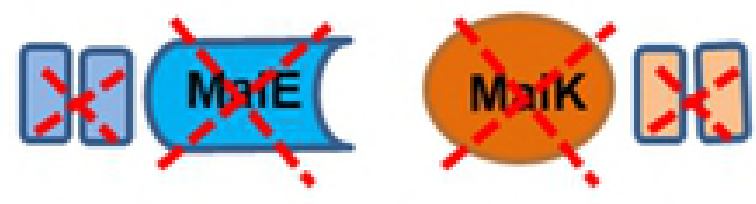

$\downarrow$

Maltose/maltodextrin uptake inhibited \& no Chemotaxis

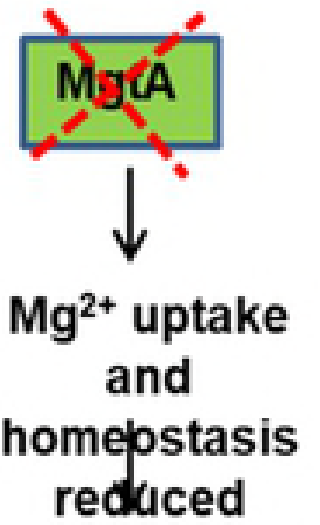

Nitro-oxidative stress kills the bacteria
Bacterial growth and virulence inhibited 